\title{
A data-driven analysis of energy balance closure across FLUXNET research sites:The role of landscape scale heterogeneity
}

Authors: Paul C. Stoy, Matthias Mauder, Thomas Foken, Barbara Marcolla, Eva Boegh, Andreas Ibrom, M. Altaf Arain, Almut Arneth, Mika Aurela, Christian Bernhofer, Alessandro Cescatti, Ebba Dellwik, Pierpaolo Duce, Damiano Gianelle, Eva van Gorsel, Gerard Kiely, Alexander Knohl, Hank Margolis, Harry McCaughey, Lutz Merbold, Leonardo Montagnani, Dario Papale, Markus Reichstein, Matthew Saunders, Penelope Serrano-Ortiz, Matteo Sottocornola, Donatella Spano, Francesco Vaccari, and Andrej Varlagin

NOTICE: this is the author's version of a work that was accepted for publication in Agricultural and Forest Meteorology. Changes resulting from the publishing process, such as peer review, editing, corrections, structural formatting, and other quality control mechanisms may not be reflected in this document. Changes may have been made to this work since it was submitted for publication. A definitive version was subsequently published in Agricultural and Forest Meteorology, volume 171/172, April 15, 2013, DOI\#10.1016/j.agrformet.2012.11.004.

Stoy, Paul, Matthias Mauder, Thomas Foken, Barbara Marcolla, Eva Boegh, Andreas Ibrom, M. Altaf Arain et al. "A data-driven analysis of energy balance closure across FLUXNET research sites: The role of landscape scale heterogeneity." Agricultural and Forest Meteorology 171-172 (2013): 137-152. 


\title{
A data-driven analysis of energy balance closure across FLUXNET research sites: The role of landscape scale heterogeneity
}

\author{
Paul C. Stoy ${ }^{\mathrm{a}, *}$, Matthias Mauder ${ }^{\mathrm{b}}$, Thomas Foken ${ }^{\mathrm{c}}$, Barbara Marcolla $^{\mathrm{d}}$, Eva Boegh ${ }^{\mathrm{e}}$, Andreas Ibrom $^{\mathrm{f}}$, \\ M. Altaf Araing ${ }^{\mathrm{g}}$, Almut Arneth ${ }^{\mathrm{b}, \mathrm{h}}$, Mika Aurela ${ }^{\mathrm{i}}$, Christian Bernhofer ${ }^{\mathrm{j}}$, Alessandro Cescatti ${ }^{\mathrm{k}}$, \\ Ebba Dellwik $^{1}$, Pierpaolo Duce ${ }^{\mathrm{m}}$, Damiano Gianelle ${ }^{\mathrm{d}}$, Eva van Gorsel ${ }^{\mathrm{n}}$, Gerard Kiely ${ }^{\mathrm{o}}$, \\ Alexander Knohl ${ }^{\mathrm{p}}$, Hank Margolis ${ }^{\mathrm{q}}$, Harry McCaughey ${ }^{\mathrm{r}}$, Lutz Merbold ${ }^{\mathrm{s}}$, Leonardo Montagnani ${ }^{\mathrm{t}, \mathrm{u}, \mathrm{v}}$, \\ Dario Papale $^{\mathrm{w}}$, Markus Reichstein ${ }^{\mathrm{x}}$, Matthew Saunders ${ }^{\mathrm{y}}$, Penelope Serrano-Ortiz ${ }^{\mathrm{z}}$, \\ Matteo Sottocornola ${ }^{\mathrm{d}}$, Donatella Spano ${ }^{\mathrm{A}}$, Francesco Vaccari ${ }^{\mathrm{m}}$, Andrej Varlagin ${ }^{\mathrm{B}}$
}

a Department of Land Resources and Environmental Science, Montana State University, Bozeman, MT, USA

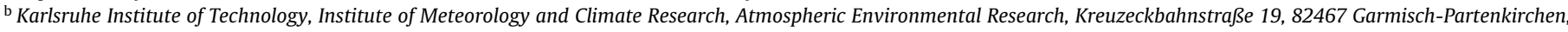
Germany

${ }^{c}$ University of Bayreuth, Department of Micrometeorology and member of Bayreuth Center of Ecology and Ecosystem Research (BayCEER), D-95440 Bayreuth, Germany

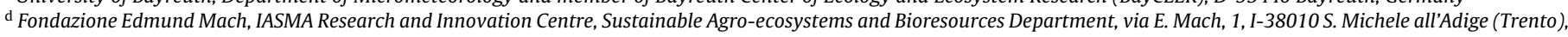
Italy

e Department of Environmental, Social and Spatial Change, Roskilde University, Universitetsvej 1, Postbox 260, 4000 Roskilde, Denmark

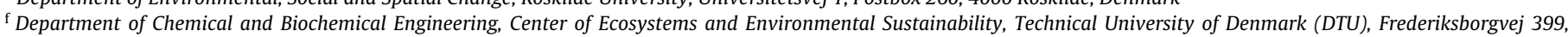
DK-4000 Roskilde, Denmark

g School of Geography and Earth Sciences, McMaster University, 1280 Main Street West, Hamilton, Ontario L8S 4K1, Canada

h Department of Physical Geography and Ecosystems Analysis, Lund University, Sölvegatan 12, 22362 Lund, Sweden

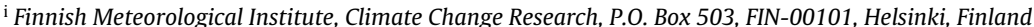

${ }^{\mathrm{j}}$ Technische Universität Dresden, Faculty of Environmental Sciences, Institute of Hydrology and Meteorology, 01062 Dresden, Germany

${ }^{k}$ European Commission - DG Joint Research Centre, Institute for Environment and Sustainability, Climate Change Unit, TP290, Via E. Fermi, 2749, I-21027 Ispra (VA), Italy

${ }^{1}$ DTU Wind Energy, Department of Wind Energy, Technical University of Denmark, Frederiksborgvej 399, 4000 Roskilde, Denmark

$\mathrm{m}$ IBIMET-CNR, Institute of Biometeorology, National Research Council, Via G. Caproni 8, 50144 Florence - Traversa La Crucca 3, 07100 Sassari, Italy

${ }^{n}$ CSIRO Marine and Atmospheric Research, Pye Laboratory, GPO Box 3023, Canberra ACT 2601, Australia

${ }^{\circ}$ Hydromet Group, Civil and Environmental Engineering Department, University College Cork, Ireland

p Georg-August University Göttingen, Büsgenweg 2, 37077 Göttingen, Germany

${ }^{q}$ Faculté de foresterie et de géomatique, Université Laval, Sainte-Foy, Quebec G1K 7P4, Canada

${ }^{\mathrm{r}}$ Department of Geography, Queen's University, Kingston, Ontario, Canada K7L3N6

${ }^{s}$ Department of Environmental Systems Science, Institute of Agricultural Sciences, ETH Zurich, Universitätsstr. 2, 8092 Zurich, Switzerland

${ }^{\mathrm{t}}$ Forest Services of Autonomous Province of Bolzano, Bolzano, Italy

u Laboratory of Chemical Physics, Agency for the Environment of Autonomous Province of Bolzano, Bolzano, Italy

${ }^{\mathrm{v}}$ Faculty of Science and Technology, Free University of Bolzano, Piazza Università 1, 39100, Bolzano, Italy

${ }^{w}$ Department for Innovation in Biological, Agro-food and Forest Systems (DIBAF), University of Tuscia, 01100 Viterbo, Italy

x Max Planck Institute for Biogeochemistry, P.O. Box 1001 64, 07701 Jena, Germany

y School of Biology \& Environmental Science, University College Dublin Science Centre, Belfield Dublin 4, Ireland

z Departamento de Desertificación y Geoecología, Estación Experimental de Zonas Áridas, CSIC, Ctra. De Sacramento s/n, Almería, Spain

${ }^{A}$ Department of Economics and Woody Plants (DESA), University of Sassari, Via de Nicola 9, 07100 Sassari, Italy

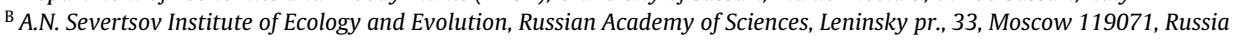

\begin{abstract}
A B S T R A C T
The energy balance at most surface-atmosphere flux research sites remains unclosed. The mechanisms underlying the discrepancy between measured energy inputs and outputs across the global FLUXNET tower network are still under debate. Recent reviews have identified exchange processes and turbulent motions at large spatial and temporal scales in heterogeneous landscapes as the primary cause of the lack of energy balance closure at some intensively-researched sites, while unmeasured storage terms cannot be ruled out as a dominant contributor to the lack of energy balance closure at many other sites. We analyzed energy balance closure across 173 ecosystems in the FLUXNET database and explored the relationship between energy balance closure and landscape heterogeneity using MODIS products and GLOBEstat elevation data. Energy balance closure per research site $\left(C_{E B, S}\right)$ averaged $0.84 \pm 0.20$, with best
\end{abstract}


average closures in evergreen broadleaf forests and savannas (0.91-0.94) and worst average closures in crops, deciduous broadleaf forests, mixed forests and wetlands (0.70-0.78). Half-hourly or hourly energy balance closure on a percent basis increased with friction velocity $(u *)$ and was highest on average under near-neutral atmospheric conditions. $C_{E B, s}$ was significantly related to mean precipitation, gross primary productivity and landscape-level enhanced vegetation index (EVI) from MODIS, and the variability in elevation, MODIS plant functional type, and MODIS EVI. A linear model including landscape-level variability in both EVI and elevation, mean precipitation, and an interaction term between EVI variability and precipitation had the lowest Akaike's information criterion value. $C_{E B, s}$ in landscapes with uniform plant functional type approached 0.9 and $C_{E B, S}$ in landscapes with uniform EVI approached 1 . These results suggest that landscape-level heterogeneity in vegetation and topography cannot be ignored as a contributor to incomplete energy balance closure at the flux network level, although net radiation measurements, biological energy assimilation, unmeasured storage terms, and the importance of good practice including site selection when making flux measurements should not be discounted. Our results suggest that future research should focus on the quantitative mechanistic relationships between energy balance closure and landscape-scale heterogeneity, and the consequences of mesoscale circulations for surface-atmosphere exchange measurements.

\section{Introduction}

The surface-atmosphere exchanges of energy, momentum, water and trace gases are central components of the Earth system. Our understanding of these processes at the ecosystem level increasingly relies on observations from single or multiple eddy covariance flux measurement towers, regional flux measurement networks (e.g. Aubinet et al., 2000; Li et al., 2005), and the global FLUXNET database (Baldocchi et al., 2001; Papale et al., 2006). Most FLUXNET studies seek to understand processes controlling the biosphere-atmosphere flux of $\mathrm{CO}_{2}$ (e.g. Baldocchi, 2008; Jung et al., 2009; Law et al., 2002; Stoy et al., 2009). Fewer studies to date have investigated global and regional water and energy fluxes apart from their relationship to $\mathrm{CO}_{2}$ flux, with notable exceptions (e.g. Falge et al., 2001; Law et al., 2002; Hollinger et al., 2009; Jung et al., 2011). The relative paucity of eddy covariance energy and water flux studies is disproportional to the importance of these fluxes to the climate system.

Water, carbon and energy flux studies that rely on eddy covariance data are challenged by incomplete energy balance closure at most research sites (Aubinet et al., 2000; Leuning et al., 2012; Wilson et al., 2002). To date, multi-site syntheses have found an average eddy covariance energy balance closure $\left(C_{E B}\right)$ ranging between 0.75 and 0.87 (Barr et al., 2006; Falge et al., 2001; Hendricks Franssen et al., 2010; Li et al., 2005; Wilson et al., 2002). Near-to-full $C_{E B}$ has been reported at some sites (e.g. Haverd et al., 2007; Heusinkveld et al., 2004; Lindroth et al., 2009; Moderow et al., 2009; Vourlitis and Oechel, 1999), but these studies are in the minority. $C_{E B}$ can be increased by measuring energy storage terms that are often excluded from conventional observations (Heusinkveld et al., 2004; Lindroth et al., 2009; Meyers and Hollinger, 2004), but additional measurements, including advective transport, often prove ineffective for closing the energy balance completely (Aubinet et al., 2010; Etzold et al., 2010; Moderow et al., 2011), in part because of the critical role of sensor accuracy for advection measurements (Dellwik et al., 2010a,b; Leuning et al., 2008). Large surface flux field campaigns have yet to report full energy balance closure (Beyrich et al., 2002; Foken, 1998; Foken et al., 1997; Kanemasu et al., 1992; Koitzsch et al., 1988; Mauder et al., 2006; Panin et al., 1998; Tsvang et al., 1991) (see Table 2 in Foken, 2008), suggesting that a fundamental aspect of surfaceatmosphere exchange has yet to be ascertained.

Foken (2008) and Panin and Bernhofer (2008) concluded that buoyancy-driven turbulent circulations resulting from landscape heterogeneity are likely responsible for energy imbalance at the tower measurement level. These studies follow work by Panin et al. (1998) and Mauder et al. (2007b), who identified a relationship between energy balance closure and landscape patterns on a spatial scale on the order of tens of kilometres. In essence, this 'mesoscale hypothesis' suggests that relatively cool and dry air layers aloft are exchanged with relatively warm and moist air layers near the surface, and both the downward motion of cooler air and upward motion of warmer air result in a positive $\overline{w^{\prime} T^{\prime}}$ that contributes to a lack of energy balance closure if this flux is unmeasured by the eddy covariance instrumentation (Fig. 1). More experimental evidence of the interaction between surface heterogeneity and mesoscale circulations were obtained from aircraft measurements (Mauder et al., 2007a) and a multi-tower experiment (Mauder et al., 2010), but potential impacts of landscape-level heterogeneity on energy balance closure has not been tested across flux networks to date.

Other results highlight the importance of correctly measuring and interpreting energy storage terms to achieve energy balance closure. A recent study by Leuning et al. (2012) found that $45 \%$ of FLUXNET sites approached energy balance closure using daily averages after correctly accounting for lags in heat flux into soils, biomass, and the canopy air space (Gao et al., 2010; Haverd et al., 2007). Accounting for all energy storage terms results in a closed energy balance at select sites (Lindroth et al., 2009).

From these studies, it is clear that a closed energy balance can occur at certain sites, yet the energy balance at hundreds of flux sites worldwide remain unclosed. We adopt a data-driven approach (Gray, 2009; Hunt et al., 2009) and combine eddy covariance and remote sensing databases to test if millions of observations are consistent with the expectations of the mesoscale hypothesis that landscape-level heterogeneity is negatively related to energy balance closure. Our objectives are twofold. First, we characterize $C_{E B}$ at 173 sites in the FLUXNET database as it relates to micrometeorological drivers, considering both half-hourly (or hourly) observations $\left(C_{E B, i}\right)$ and site-level means $\left(C_{E B, S}\right)$. We then test the hypothesis that energy balance closure is related to landscape-level heterogeneity using data products from the Moderate-Resolution

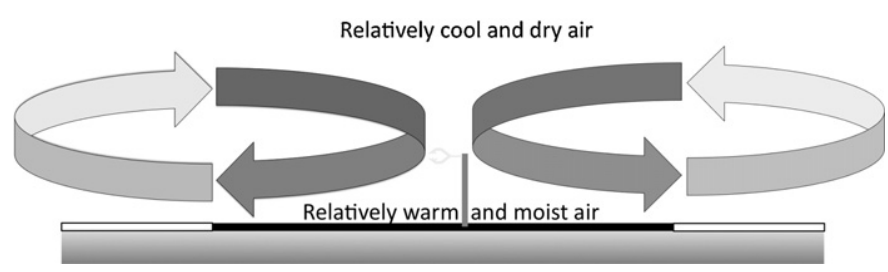

Fig. 1. Conceptual description of mesoscale circulations, driven in part by landscape-level heterogeneity, suggested by Foken et al. (2011), Mauder et al. (2010) and others to contribute to lack of energy balance closure at single-tower sites. The anisotropic nature of the mesoscale circulations is on the order of tens of kilometres in the horizontal direction. 
Imaging Spectroradiometer (MODIS) and the GLOBEsat elevation data set. We hypothesize that $C_{E B}$ is related to landscape-level heterogeneity following the conclusions of Foken et al. (2011).

\section{Methods}

\subsection{FLUXNET: instantaneous energy balance closure}

Flux and meteorological data from the LaThuile FLUXNET database [www.fluxdata.org, accessed May 31, 2008] and processed according to FLUXNET protocols (Papale et al., 2006; Reichstein et al., 2005) were used here. Energy balance closure on the half-hourly or hourly basis is denoted for the purposes of this analysis as 'instantaneous' $\left(C_{E B, i}\right)$, and was calculated as:

$C_{E B, i}=\frac{\lambda E+H}{R_{n}-G-J}$

i.e. the fraction of available energy defined as the net radiation $\left(R_{n}\right)$ minus soil heat flux $(G)$ that is realized as surface-atmosphere turbulent fluxes of latent heat $(\lambda E)$ and sensible heat $(H)$. Minor storage and metabolic terms $(J)$ were set to zero here as they are neither included in the database nor measured at most FLUXNET sites, but their inclusion is important for $C_{E B}$ at many sites (Haverd et al., 2007; Lindroth et al., 2009). $C_{E B, i}$ data for which all measured terms in equation 1 pass the FLUXNET quality control criteria (Papale et al., 2006), and for which friction velocity $(u *)$ measurements were available, are examined here; no gapfilled data products were used.

During periods when energy fluxes are small, $C_{E B, i}$ may degrade although the absolute energy balance residual is only a few $\mathrm{W} \mathrm{m}^{-2}$, which is of minor concern. For a comprehensive interpretation of the results, we also exploree the absolute energy balance residual, which can be defined as:

$R_{E B, i}=R_{n}-G-\lambda E-H-J$

with $J$ again set to zero.

\subsection{FLUXNET: energy balance closure per site}

For the analysis of energy balance closure per site, we explored the 173 (of 253) sites, where observations of $R_{n}, \lambda E, H$, and $G$ were available (Table A1). Two sites with energy balance closure greater than 2 were excluded for quality control concerns. Energy balance closure for each site, $C_{E B, S}$, was defined as:

$C_{E B, i}=\frac{\sum(\lambda E+H)}{\sum\left(R_{n}-G-J\right)}$

again assuming that $J$ is negligible. This approach is sometimes called the 'bulk method' (Hendricks Franssen et al., 2010), the energy balance ratio (Wilson et al., 2002), or the relative energy balance closure (Aubinet et al., 2000). Half-hourly data for which $R_{n}, \lambda E, H$, and $G$ were measured and passed quality-control criteria, including sufficient $u *$ to assure turbulent transport for the turbulent flux terms (Reichstein et al., 2005), were converted from $\mathrm{W} \mathrm{m}^{-2}$ to $\mathrm{J} \mathrm{m}^{-2}$ per half hour (or hour) and summed for the calculation of $C_{E B, s}$. We note that the apparent lack of energy balance closure need not constitute evidence for erroneous turbulent flux measurements (Aubinet et al., 2000).

Both $C_{E B, S}$ and mean $C_{E B, i}$ may be expected to be somewhat less than unity if energy storage in the aboveground vegetation, in the canopy air space, above the soil heat flux plates, and owing to metabolism (i.e. the terms that contribute to $J$ ) are not considered. We note that energy storage terms average out on an annual basis under steady-state conditions. Choosing only individual years with excellent data acceptability ( $>90 \%$ ) to further minimize the role of canopy and soil heat storage variability does not change mean $C_{E B, S}$ (data not shown). Regardless, one may assume that metabolism and unmeasured storage terms contribute to $C_{E B}$. We test surrogates for metabolism using gross primary productivity (GPP) and we use precipitation $(\mathrm{P})$ as a surrogate for soil moisture, a primary control over soil heat storage, which is seldom reported in the FLUXNET database. For the statistical analyses, we treat each FLUXNET site, not site-year, as independent.

\subsection{Environmental variables}

Energy balance closure can be expected to be a function of $u *$ and atmospheric stability (Aubinet et al., 2000), both of which vary diurnally in most instances. We explore relationships between $C_{E B, i}$ and $u_{*}$, the solar zenith angle, and the Obukhov length $(L)$ as a primary determinant of atmospheric stability using:

$L=\frac{-\rho C_{p} u_{*}^{3} T}{k g H}$

where $\rho$ is the density of air, $C_{p}$ is the specific heat capacity of dry air, $k$ is von Kármán's constant, $g$ is gravitational acceleration and $T$ is air temperature in Kelvin.

Daytime periods are defined as those during which the solar zenith angle is less than $90^{\circ}$. To differentiate between morning and afternoon we define 'zenith 2 ' as the solar zenith angle with periods before solar noon denoted as negative.

\subsection{Kernel density estimation}

Visualizing relationships amongst millions of observations is a formidable challenge. We used two-dimensional kernel density estimates to present the relationships amongst $C_{E B, i}$ and environmental variables. Kernel density estimation is a non-parametric approach for estimating probability density functions from a given dataset. Histograms are the simplest non-parametric density estimator, but suffer from the arbitrary choice of bin size. Kernel density estimators place a smooth kernel (usually a Gaussian window, also chosen here) with a given bandwidth about measured data points, and combine these to create an estimate of the probability distribution of all observations. We used a linear diffusion algorithm following Botev et al. (2010) to choose optimal kernel bandwidths and avoid over- or under-smoothing. Kernel density estimation is used here to improve visual display rather than for the statistical interpretation of the data, and like a probability distribution or density function the sum of all kernel density values equals one.

\subsection{MODIS: land cover classifications}

Following the suggestions of Foken (2008), the landscape characteristics of the $20 \times 20 \mathrm{~km}$ area surrounding the 173 flux towers were analyzed in relation to $C_{E B, s}$. The $20 \mathrm{~km}$ length scale was suggested to be representative of anisotropic atmospheric motions that exhibit statistical stationarity (Mauder et al., 2007a). The MODIS MCD12Q1 PFT (plant functional type) land cover classification product was downloaded for the $20 \times 20 \mathrm{~km}$ areas surrounding all 173 towers for 2006. As these data are categorical, an appropriate metric for their variability is their information entropy after Shannon (1948):

$I(X)=-\sum_{i=1}^{N} p\left(x_{i}\right) \ln p\left(x_{i}\right)$

where $N$ is the number of bins that a pixel can take for each attribute and $p\left(x_{i}\right)$ is the fraction of pixels in each bin $i$ representing each different MODIS PFT classification. The PFT product has 12 classes 

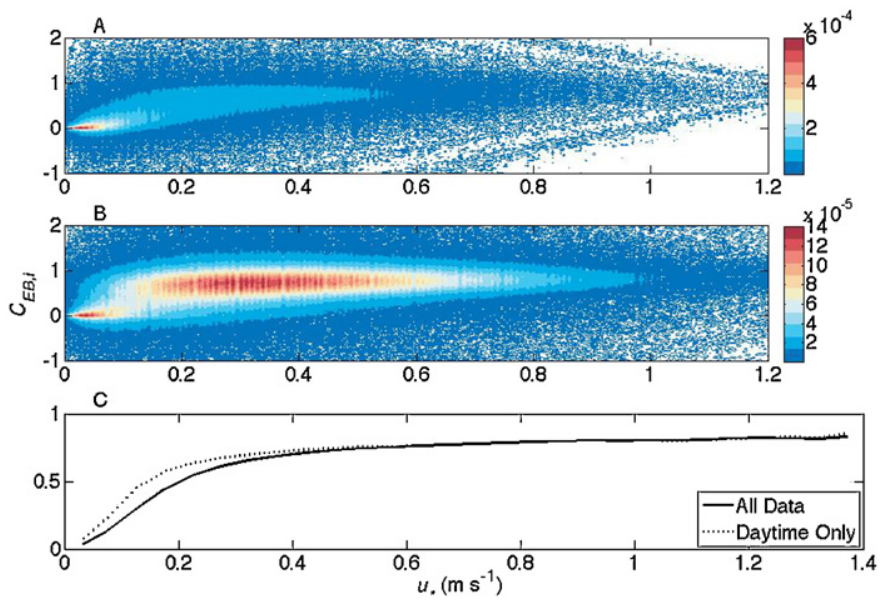

Fig. 2. The instantaneous energy balance closure, $C_{E B, i}$ as a function of the friction velocity $\left(u_{*}, \mathrm{~m} \mathrm{~s}^{-1}\right)$ for all observations (A) and daytime periods (B) for which the solar zenith angle was less than $90^{\circ}$ plotted as a distribution using a two-dimensional kernel density estimate. The colorbar denotes probabilities. Subplot $\mathrm{C}$ is the median $C_{E B, i}$ per $u *$ bin.

( water $=0$, evergreen needle leaf forest $=1$, evergreen broadleaf forest $=2$, etc.), therefore $N=12$ and the Shannon entropy of a uniform landscape with a single plant functional type is zero. Unfilled and unknown MODIS pixels were excluded from the entropy calculations.

\subsection{MODIS: enhanced vegetation index (EVI)}

We chose the MODIS product with the highest spatial resolution, $250 \mathrm{~m}$ in the MOD13Q1 product, for the calculation of EVI in the $20 \times 20 \mathrm{~km}$ area surrounding the 173 flux towers analyzed here. EVI was chosen over the normalized difference vegetation index (NDVI) because of the saturating NDVI-leaf area index (LAI) relationship in forest canopies (Huete et al., 2002). EVI was chosen over LAI to avoid uncertainties in the MODIS LAI algorithm.

The 16-day resolution of the MOD13Q1 EVI product creates a challenge for quantifying a simple metric of landscape-level variability. A full spatiotemporal analysis of EVI across 173 sites is complicated by quality control issues including the presence of clouds and/or snow. To simplify the comparison between $C_{E B, S}$ and EVI, we obtained $20 \times 20 \mathrm{~km}$ EVI data for each site for 2005-2007, and chose the scene with the greatest amount of reliable data that had the highest mean EVI. This approach calculated landscape-level variability with high data quality during growing season periods when incident solar radiation was greatest, on average, and when most energy on an absolute basis tends to go missing (see Fig. 4C). The total variance of the EVI observations across the $20 \times 20 \mathrm{~km}$ region, $\sigma^{2}(E V I)$, was used as the metric of landscape-level heterogeneity in subsequent analyses. We also investigated the mean EVI, $\mu(E V I)$, at the tower location to explore the effects of canopy density (as a surrogate for heat storage in the canopy) in determining $C_{E B, s}$. Per the recommendations of the MODIS land surface project team, the average of the nine MODIS pixels surrounding and including the flux tower was taken to represent $\mu(E V I)$.

\section{Results}

\subsection{Instantaneous energy balance closure}

The FLUXNET quality control criteria (Papale et al., 2006) were met by nearly $7.7 \times 10^{6}$ half-hourly (or hourly) data points. $C_{E B, i}$ as a function of $u *$ is shown in Fig. 2. The peak of the 2D kernel density estimate between $u *$ and $C_{E B, i}$ lies near the origin (Fig. $2 \mathrm{~A}$ ), but
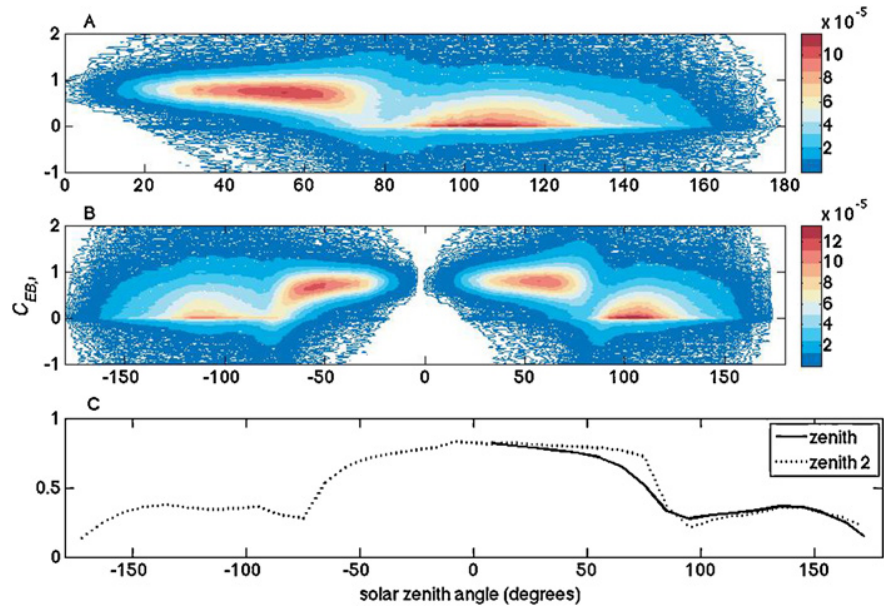

Fig. 3. The instantaneous energy balance closure, $C_{E B, i}$ as a function of (A) solar zenith angle and (B) adjusted zenith angle ('Zenith 2') in which all times between midnight and solar noon (i.e. morning) are denoted as negative. The colorbar denotes probabilities following Fig. 2. Subplot $C$ is the median $C_{E B, i}$ per solar zenith angle bin.

shifts to a space between ca. 0.2 and $0.5 \mathrm{~m} \mathrm{~s}^{-1}$ when only daytime data are considered (Fig. 2B). The median $C_{E B, i}$ per $u *$ bin increases quickly until a $u *$ value of about $0.2 \mathrm{~m} \mathrm{~s}^{-1}$ is reached, and continues to increase albeit with a smaller slope at higher $u *$ values (Fig. 2C) and does not reach unity.

$C_{E B, i}$ is consistently low during nighttime periods with solar zenith angles $>90^{\circ}$, especially during the day/night and night/day transitions (Fig. 3A). $C_{E B, i}$ increases more slowly during the morning than the corresponding decrease in the afternoon (Fig. 3B). Median $C_{E B, i}$ approaches 0.8 under near-neutral conditions and decreases as the atmosphere becomes more stable or unstable (Fig. $4 \mathrm{~A}$ and $\mathrm{B})$. The energy balance residual $\left(R_{E B, i}\right)$ is also higher during nearneutral periods when both $C_{E B, i}$ and $u *$ are highest (Fig. $4 C$ and D). $u *$ and $H$ enter into the calculation of $L$ and are shown with respect to $L$ in Fig. 4 for reference.

Of the 173 sites explored here, 73 sites show significantly lower $C_{E B, i}$ as a function of time from the beginning to the end of the measurement record, 69 sites have significantly higher $C_{E B, i}$ over time, and 31 sites were unchanged. In other words, energy balance closure declined over the measurement period at over $40 \%$ of the sites studied here.

\subsection{Site-level energy balance closure}

The mean (standard deviation) of the energy balance closure, $C_{E B, s}$, for the 173 sites listed in Table A1 is $0.84 \pm 0.20$ (Table 1 ). $C_{E B, S}$ ranges from 0.28 to 1.67 after excluding severe outliers that were not analyzed on account of quality control concerns. The slope and intercept of the relationship between $\Sigma\left(R_{n}-G\right)$ and $\Sigma(\lambda E+H)$ for all sites (with $95 \%$ confidence intervals in parentheses) are 0.82 $( \pm 0.035)$ and $57( \pm 261) \mathrm{MJ} \mathrm{m}^{-2}$ (Fig. 5). The intercept is not statistically different from zero.

Table 1

The mean and standard deviation of the energy balance closure $\left(C_{E B}\right)$ in the FLUXNET database for different plant functional type groupings.

\begin{tabular}{lrl}
\hline & $n$ & $C_{E B}$ \\
\hline All & 173 & $0.84 \pm 0.20$ \\
Forest & 88 & $0.83 \pm 0.22$ \\
Non-forest & 57 & $0.83 \pm 0.19$ \\
Other $^{\mathrm{a}}$ & 28 & $0.87 \pm 0.15$ \\
\hline
\end{tabular}

a Savannas, shrublands and wetlands that may or may not be dominated by woody vegetation. 

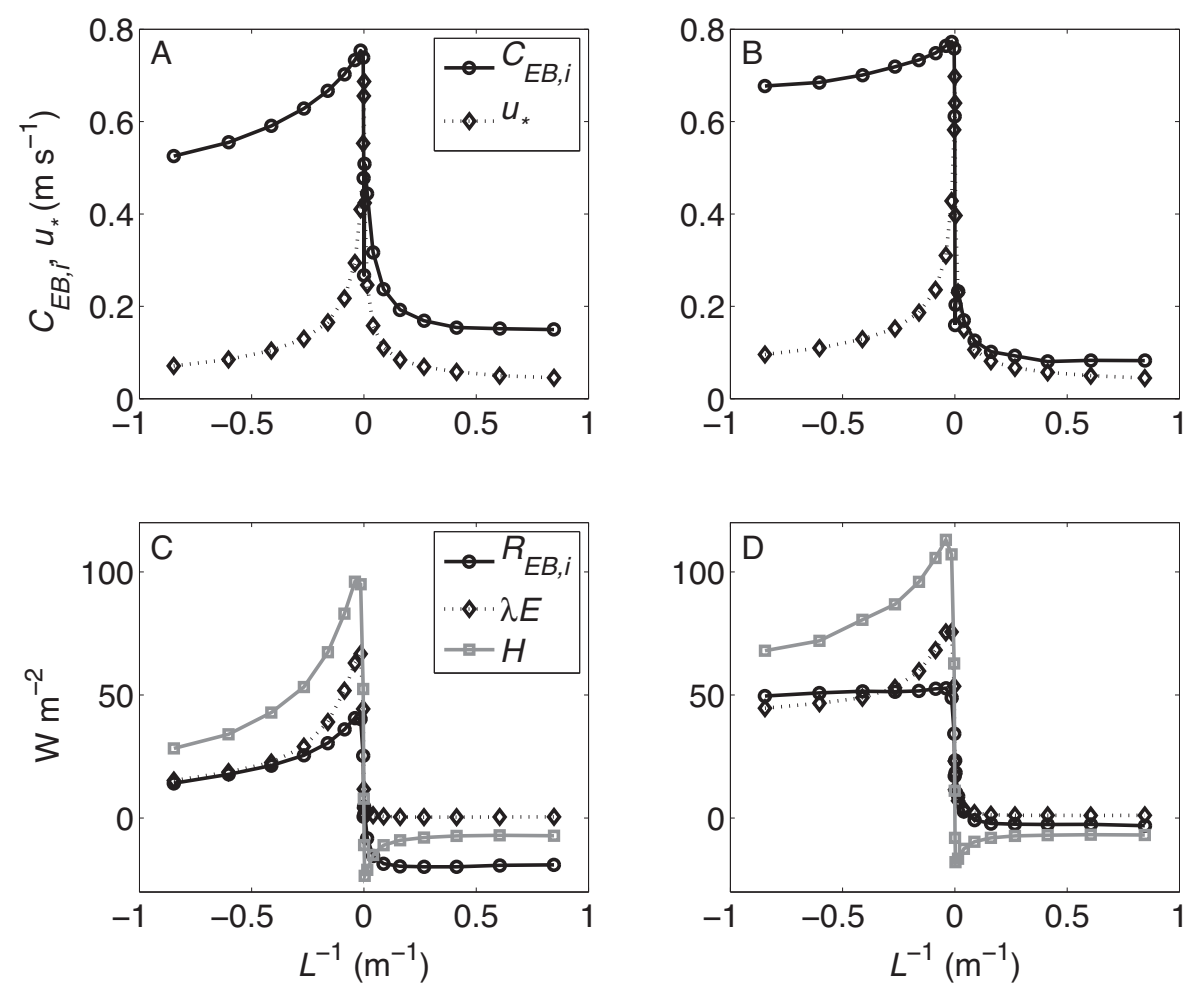

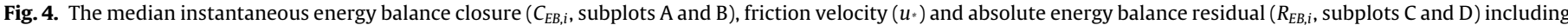

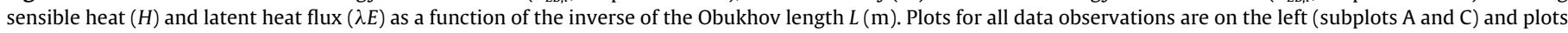
for daytime only periods (with solar zenith angle $<90^{\circ}$ ) are on the right (subplots B and D).

Mean $C_{E B, s}$ for different vegetation types are listed in Table 2. Evergreen broadleaf forests and savannas tend to have the highest values of $C_{E B, s}$, and deciduous broadleaf forests, mixed forests, crops and wetlands the lowest. The $C_{E B, S}$ of forests $(0.83 \pm 0.22)$ shortstatured vegetation $(0.83 \pm 0.18)$, and other vegetation (grouped as savannas and wetlands, $0.87 \pm 0.19$ ) do not differ as determined by a two-sided $t$-test $(p>0.05)$ and a two-sample KolmogorovSmirnov test at the 0.05 probability level. $C_{E B, i}$ is not related to the Bowen ratio (data not shown), but site-level $C_{E B}\left(C_{E B, S}\right)$ is negatively related to the site-level Bowen ratio $(\Sigma H / \Sigma \lambda E ; r=-0.16 ; p=0.04)$.

\subsection{Energy balance closure in relationship to landscape variability}

MODIS PFT and EVI for the $20 \times 20 \mathrm{~km}$ area surrounding the tower in Hainich Forest, Germany are shown as examples in Fig. 6. There is a significant negative relationship $(r=-0.17 ; p=0.011)$ between $C_{E B, s}$ and $I(\mathrm{PFT})$ with an intercept at 0.89 , suggesting that energy balance closure approaches ca. 0.9 in landscapes with uniform vegetation type. $C_{E B, S}$ is significantly related to both $\mu(E V I)$ in the nine pixels surrounding the tower $(r=-0.20$; $p=0.008)$ and $\sigma^{2}(E V I)$ for the $20 \times 20 \mathrm{~km}$ area surrounding the tower (Fig. 7, $r=-0.21 ; p=0.004$ ) even after excluding obvious outliers $\left[\sigma^{2}(E V I)>0.04\right]$ that may have spuriously influenced this relationship $(r=-0.24 ; p=0.001)$. The intercept is not statistically different than unity.

\subsection{Models for energy balance closure}

$C_{E B, S}$ is significantly related to MODIS PFT and EVI, but also to mean precipitation, GPP, the site-level Bowen ratio, and landscapelevel variability in elevation derived from the GLOBEsat elevation dataset ( $p<0.05$ in all cases). We created linear models of the variables that contribute to $C_{E B, S}$, and subjected these to information criterion analyses to identify a minimal model for $C_{E B, s}$. The minimal model identified by the Akaike information criterion

Table 2

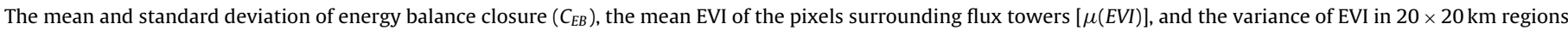

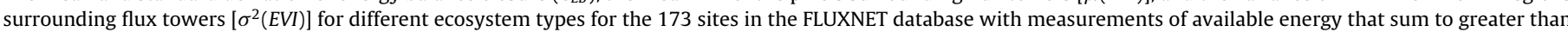
zero. Three sites had no available ecosystem type information and are excluded from this table but are included in the analysis.

\begin{tabular}{|c|c|c|c|c|c|}
\hline Vegetation type & Abbrev. & $n$ & $C_{E B}$ & $\mu(E V I)$ & $\sigma^{2}(E V I)$ \\
\hline Crops & CRO & 25 & $0.78 \pm 0.16$ & $0.45 \pm 0.13$ & $0.014 \pm 6.9 \times 10^{-3}$ \\
\hline Shrubs $^{\mathrm{a}}$ & SHR & 9 & $0.87 \pm 0.15$ & $0.32 \pm 0.16$ & $0.010 \pm 8.4 \times 10^{-3}$ \\
\hline Deciduous Broadleaf Forest & DBF & 20 & $0.70 \pm 0.19$ & $0.47 \pm 0.12$ & $0.014 \pm 7.6 \times 10^{-3}$ \\
\hline Evergreen Broadleaf Forest & $\mathrm{EBF}$ & 10 & $0.94 \pm 0.16$ & $0.39 \pm 0.12$ & $0.008 \pm 5.9 \times 10^{-3}$ \\
\hline Evergreen Needleleaf Forest & ENF & 47 & $0.88 \pm 0.23$ & $0.43 \pm 0.11$ & $0.013 \pm 1.2 \times 10^{-2}$ \\
\hline Grasslands & GRA & 32 & $0.86 \pm 0.20$ & $0.42 \pm 0.12$ & $0.010 \pm 5.5 \times 10^{-3}$ \\
\hline Mixed Forest & $\mathrm{MF}$ & 10 & $0.79 \pm 0.18$ & $0.47 \pm 0.13$ & $0.011 \pm 4.4 \times 10^{-3}$ \\
\hline Savanna ${ }^{b}$ & SAV & 10 & $0.91 \pm 0.14$ & $0.36 \pm 0.11$ & $0.007 \pm 4.6 \times 10^{-3}$ \\
\hline Wetlands & WET & 7 & $0.76 \pm 0.13$ & $0.39 \pm 0.13$ & $0.007 \pm 4.5 \times 10^{-3}$ \\
\hline
\end{tabular}

\footnotetext{
a Open and closed shrublands.
}

b Savannas and woody savannas. 


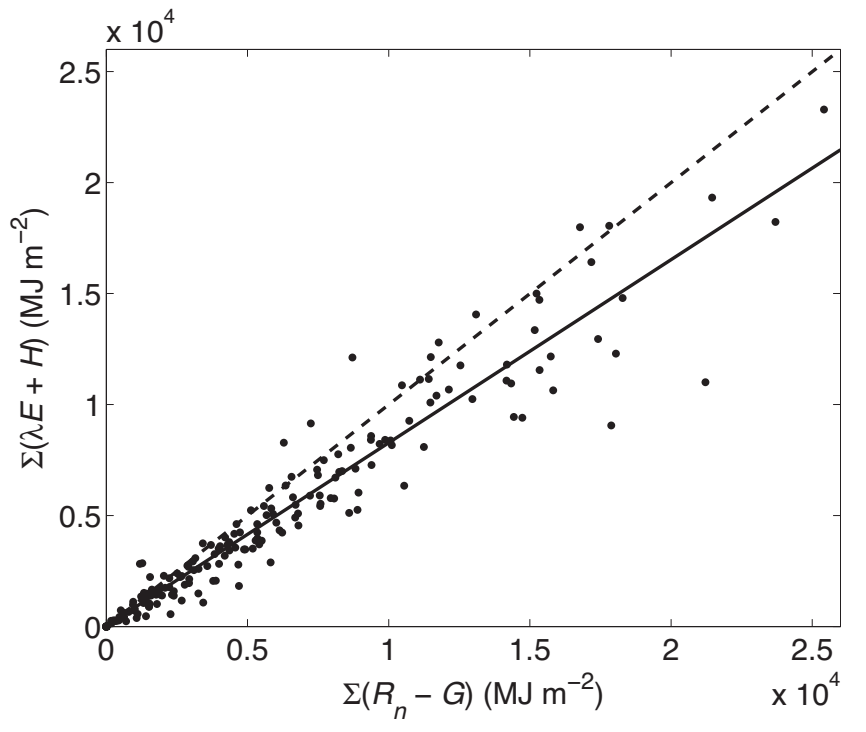

Fig. 5. The relationship between the cumulative sum of available energy (net radiation, $R_{n}$ minus soil heat flux, $G$ ) and the cumulative sum of surface fluxes of latent heat $(\lambda E)$ and sensible heat $(H)$ for each of the 173 research sites in the FLUXNET database for which all four variables are measured and sum to a positive value. The slope of the best-fit linear relationship, in black, is $0.82( \pm 0.035)$ and the intercept is $57( \pm 261) \mathrm{MJ} \mathrm{m}^{-2}$ for the measurement record of each site. The 1:1 relationship is shown as a black dashed line.

included $\sigma^{2}(E V I)$, mean precipitation, landscape-level variability in elevation, and an interaction term between $\sigma^{2}(E V I)$ and mean precipitation. A model with only $\sigma^{2}(E V I)$ and mean precipitation had the lowest value of the Bayesian information criterion.

\section{Discussion}

\subsection{Instantaneous energy balance closure}

More energy (i.e. $R_{E B, i}$ ) goes missing during periods with better relative energy balance closure, which tend to occur during daytime (Fig. 4, Hendricks Franssen et al., 2010; Wilson et al., 2002). Research on energy balance closure and surface atmosphere exchange should continue to focus on the challenges presented by both daytime and nighttime conditions. However, as more energy goes missing during daytime periods (when more energy is available), breakthroughs in understanding the energy balance closure problem will likely come with a focus on daytime periods. We also note that mornings tend to have slightly worse $C_{E B, i}$ (Fig. 3) and higher $R_{E B, i}$ (data not shown) when $G$ and the storage terms that contribute to $J$ tend to be positive rather than later in the afternoon when $G$ and $J$ have peaked or are decreasing (Hendricks Franssen et al., 2010; Leuning et al., 2012), demonstrating the importance of accounting for storage terms in the energy balance. Median $C_{E B, i}$ is only ca. 0.8 during near-neutral conditions and decreases to nearly 0.7 during highly unstable conditions (Fig. 4; Aubinet et al., 2000; Hendricks Franssen et al., 2010). In other words, periods dominated by the convective production of turbulent kinetic energy, often characterized by larger eddies, have lower energy balance closure on average.

\subsection{Energy balance closure per FLUXNET site}

Mean $C_{E B, s}$ of the 173 FLUXNET sites investigated here (0.84) is of a similar magnitude to many previous multi-site synthesis (0.79, ranging from 0.53 to 0.99 (Wilson et al., 2002); 0.84, ranging from 0.58 to 1 (Li et al., 2005; Yu et al., 2006)) if not slightly worse than other syntheses (0.85-0.89, Barr et al., 2006). $G$ may be
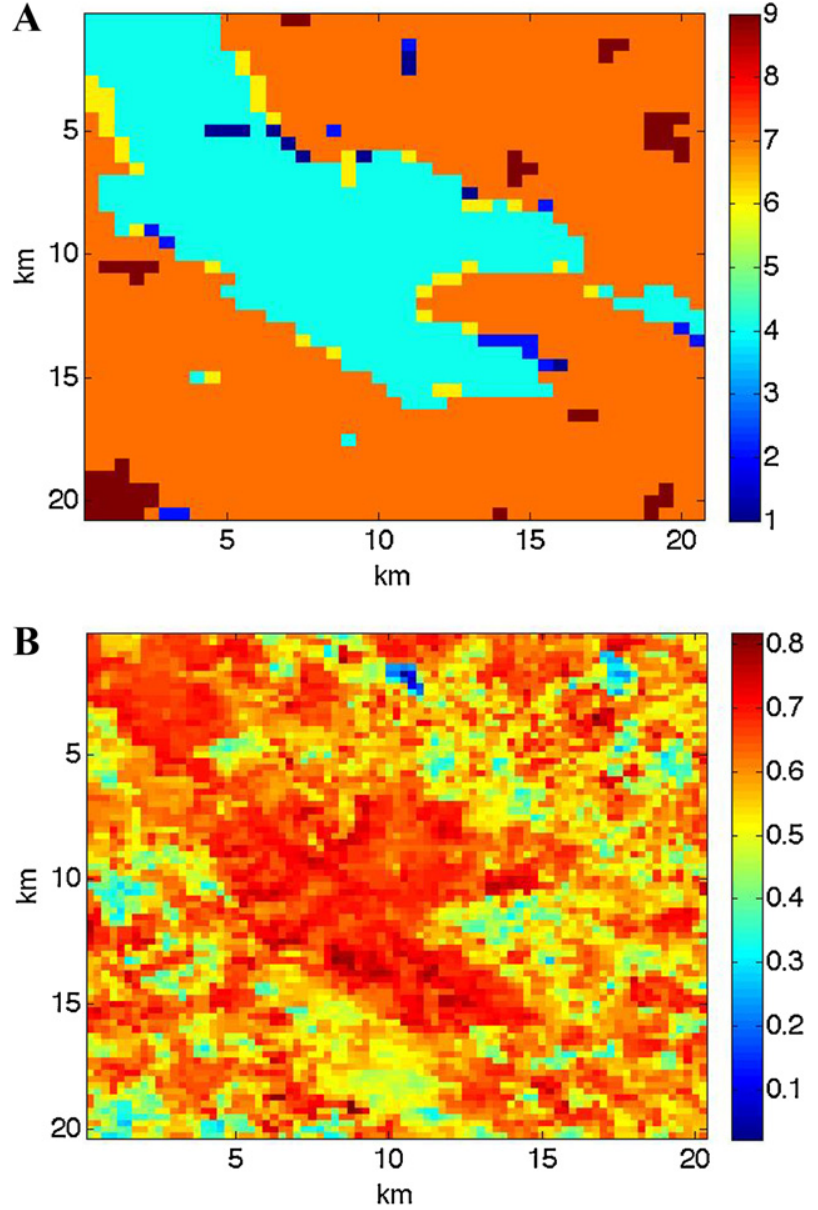

Fig. 6. The MODIS MCD12Q1 plant functional type (PFT) for the $20 \times 20 \mathrm{~km}$ area surrounding the Hainich deciduous broadleaf forest, Germany for 2006 (A) and the MODIS MOD13Q1 enhanced vegetation index (EVI) for the same area, measured on DOY 177, 2005 (B). The eddy covariance tower site is at the center point of both scenes. The legend for subpanel A follows the MODIS PFT convention. The entropy of plant functional type, $I(\mathrm{PFT})$, for Fig. $5 \mathrm{~A}$ is 0.90 and the variance of EVI, $\sigma^{2}(E V I)$, of Fig. $5 \mathrm{~B}$ is $8.6 \times 10^{-3}$.

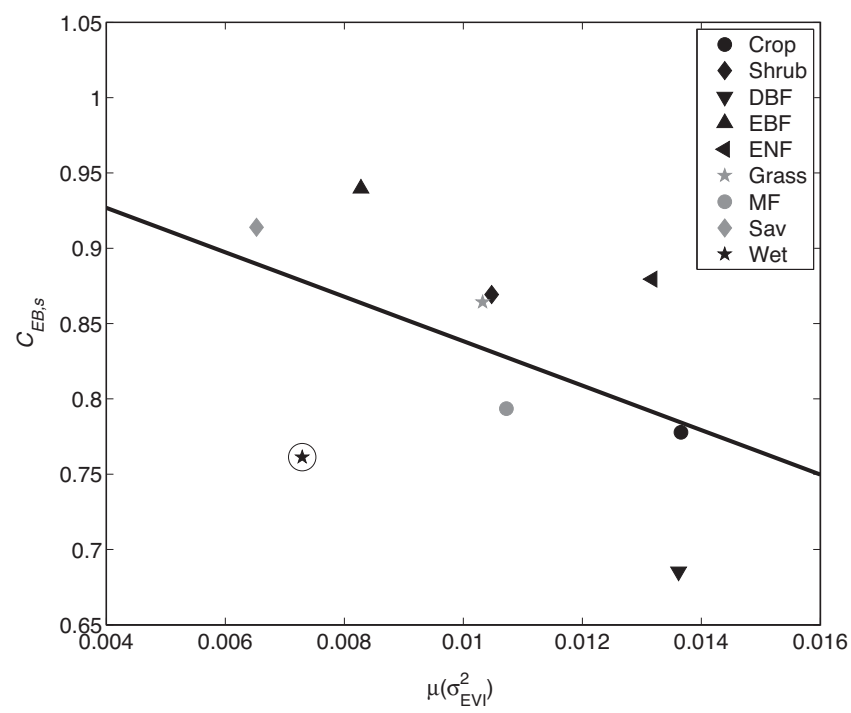

Fig. 7. Energy balance closure for FLUXNET eddy covariance research sites $\left(C_{E B, S}\right)$ as a function of the variance of the MODIS enhanced vegetation index (EVI) for the $20 \times 20 \mathrm{~km}$ region surrounding each eddy covariance tower and averaged per ecosystem type. The solid line is the best-fit relationship after removing wetland ecosystem types and is defined as $C_{E B, s}=-14.76 \mu\left(\sigma_{E V I}^{2}\right)+0.99$. Excluding wetland sites (circled) results in a squared correlation coefficient of 0.54 . 
underestimated in many instances (Hsieh et al., 2009), suggesting that any system-wide underestimation in energy balance closure would likely occur in ecosystems with more incident radiation upon the soil surface. However, $C_{E B, s}$ tends to be higher in sites with lower $\mu(E V I)$ and there is no difference in $C_{E B, s}$ among forested and non-forested ecosystems. Combined with the observation that $C_{E B, i}$ is slightly lower on average during morning periods when $G$ tends to increase, these results demonstrate that the correct measurement of $G$ is a critical component of energy balance analyses, but by itself will not close the energy balance across many FLUXNET sites (Leuning et al., 2012).

The question remains, why is the energy balance not closed at most tower sites? One might expect forests to have lower or at least significantly different $C_{E B, S}$ than short-statured vegetation, because the role of heat storage in the larger canopy, lower average $G$, and possible advection and/or decoupling of above and below canopy flows in the larger canopy air space (Cava et al., 2008; Lindroth et al., 2009; Meyers and Hollinger, 2004; Moderow et al., 2009; Staebler and Fitzjarrald, 2004). Although these impacts may be important at many individual forest sites, the mean $C_{E B, S}$ in our analysis did not differ among forest and non-forest sites, suggesting that other mechanisms are also at play. The finding that $C_{E B, i}$ is lower during unstable conditions (Fig. 4; Aubinet et al., 2000) hints that mechanisms that drive convection may contribute to the lack of energy balance closure.

\subsection{Landscape heterogeneity and energy balance closure}

The large number of sites in this analysis permits us to perform a cautious interpretation of $C_{E B, S}$ for different vegetation types. If forest and non-forest ecosystems do not differ with respect to $C_{E B, S}$, why should $C_{E B, S}$ for grasslands average 0.86 but $C_{E B, S}$ for crops average 0.78 (Table 2, Fig. 7)? Likewise, why should evergreen broadleaf forests have nearly complete closure on average (0.94) when mean $C_{E B, S}$ for deciduous broadleaf forests is only 0.70 ? Our dataset shows that there are systematic relationships between vegetation types and landscape heterogeneity, e.g., savanna sites are found in more homogeneous landscapes than deciduous forest sites (Fig. 7). This might either be specific for the biome or an effect of the flux tower site selection. Differences in vegetation types (i.e. short vs. tall vegetation) cannot explain $C_{E B, s}$, but $C_{E B, s}$ varies systematically with landscape-level heterogeneity (Fig. 7). We argue therefore that landscape-level variability plays an important role that is often overlooked in single tower investigations by the flux measurement community.

In contrast, many studies of boundary-layer meteorology and turbulence place emphasis on the role of landscape-level heterogeneity on determining boundary layer dynamics (e.g. Shen and Leclerc, 1995). Some of these findings link strongly to the present analysis. For example, Baidya Roy et al. (2003) compared Regional Atmospheric Modeling System (RAMS) output across domains with different characteristic length scales in the central U.S. (longer than $25 \mathrm{~km}$ ) and the Amazon (3-5 km). Heterogeneity in $H$ occurred at across a wide range of length scales during boundary layer development, but eddies within the $10-20 \mathrm{~km}$ scale range intensified and organized into coherent structures by early afternoon in both cases, which dominated the dynamics of turbulence. Future work should further investigate the role of such organized coherent structures on the measured energy balance closure near the surface.

Foken (2008) reviewed the results of multiple large surface flux campaigns and argued that the problem of eddy covariance energy balance closure is fundamentally a problem of scale: lower frequency motions (Foken et al., 2006; Mauder et al., 2007a; Panin et al., 1998), possibly resulting from surface heterogeneity at the landscape scale (Mauder et al., 2010), explain in part the lack of energy balance closure. Our results agree with these conclusions; landscape-level heterogeneity, here quantified by the $I(\mathrm{PFT})$ and $\sigma^{2}(E V I)$ (Fig. 7) is significantly related to $C_{E B, s}$. Both the Akaike and Bayesian information criteria suggested that $\sigma^{2}(E V I)$ should not be excluded from models for $C_{E B, s}$. These empirical relationships become more clear with the graphical representation of Table 2 in Fig. 7; grasslands and evergreen broadleaf forests in the FLUXNET database tend to lie in homogeneous areas with low $\sigma^{2}(E V I)$, and crops and deciduous broadleaf forests tend to lie in heterogeneous areas with high $\sigma^{2}(E V I)$. Excluding wetlands, $\sigma^{2}(E V I)$ explains $54 \%$ of the variance in $C_{E B, i}$ when averaged by plant functional type.

Leuning et al. (2012) point out that mesoscale circulations are unlikely to fully close the energy balance at many sites if mean vertical wind velocities on the order of $20-40 \mathrm{~mm} \mathrm{~s}^{-1}$ are required for advective flux divergence errors on the order of $50-100 \mathrm{~W} \mathrm{~m}^{-2}$ for vertical temperature differences of $2 \mathrm{~K}$. Mauder et al. (2010) demonstrated that such mean vertical wind velocities are possible in a heterogeneous agricultural landscape. Characteristic values of mean vertical wind velocity across global eddy covariance sites remain uncertain, as do their temporal variability, and the contribution of mesoscale circulations to lack of energy balance closure at different sites remains unclear.

Our analysis does not suggest that landscape-level variability is the only contributing factor to $C_{E B, S}$, in fact many variables investigated here are significantly related to $C_{E B, s}$. The role of water (approximated by $P$ ), with its large heat capacity, also plays an important role in $C_{E B, S}$ noting the low $C_{E B, S}$ of wetlands (Fig. 7) and the relationship between $C_{E B, s}$ and $P$ in the linear models. This result agrees with Leuning et al. (2012) and others that demonstrate that energy storage terms cannot be excluded as a principal contributor to the lack of energy balance closure. Landscape-level variability in topography is an important factor contributing to lack of closure, as one might anticipate given the challenges of measuring surfaceatmosphere flux in topographically diverse terrain. Relationships with latitude and seasonality should also be explored further. The information criteria analyses suggest that landscape-level variability in vegetation and topography and indices of ecosystem water content should not be excluded when interpreting the surface-atmosphere energy balance at the network level. Consistent measurements of soil moisture across the tower network will likely add clarity to the role of energy storage and hydrological advection on energy balance closure. Our findings place observations from FLUXNET in agreement with the major results from large surface-atmosphere exchange observation campaigns (Foken, 2008; Foken et al., 2006; Mauder et al., 2007a; Panin et al., 1998). It is important to note that invoking landscape-level arguments undoubtedly does not take the place of proper practice when measuring surface-atmosphere exchange at a point.

The surface heterogeneity relationships, whereas significant, have substantial scatter as may be expected given the multiple factors that contribute to the lack of closure (Fig. 7). These include sensor separation and high frequency losses (Clement et al., 2009) (especially for latent heat flux measurements with closed-path sensors (Ibrom et al., 2007)), footprint variability in space and time (Oren et al., 2006), unmeasured energy fluxes (i.e. 'minor terms'; Oncley et al., 2007) including canopy heat storage (Lindroth et al., 2009; Moderow et al., 2009) and metabolic terms (Meyers and Hollinger, 2004), instrument biases in radiation measurements (Brotzke and Duchon, 2000), advection (Aubinet et al., 2010; Moderow et al., 2011), the length of the averaging period (Malhi et al., 1998; Sanchez et al., 2010; Voronovich and Kiely, 2007), sonic angle of attack (Cava et al., 2008; Nakai et al., 2006), G measurement accuracy (Hsieh et al., 2009) and open versus closed path methodologies (Burba et al., 2008; Teklemariam et al., 2009). Different explanations for lack of energy balance closure are likely to 
dominate at different sites (Kidston et al., 2010; Moncrieff et al., 1996).

The mechanisms relating surface heterogeneity to $C_{E B, s}$ can only be inferred with the available data. If, in fact, surface heterogeneity contributes to buoyancy-driven turbulent circulations (Foken, 2008), the best strategy for including the flux information contained in these larger atmospheric motions remains to be discovered. Longer averaging periods are frequently cited (Cava et al., 2008; Finnigan et al., 2003; Malhi et al., 1998; Mauder and Foken, 2006), but this comes at the expense of capturing the diurnal variability in flux and may violate the steady state criterion underlying EC measurements. Accounting for turbulent organized structures (Badiya Roy and Avissar, 2002; Kanda et al., 2004; Steinfeld et al., 2007) may improve energy balance closure if simple parameterizations can be found. If larger atmospheric motions dominate $C_{E B, s}, \mathrm{CO}_{2}$, water and energy flux estimates should not be simply adjusted for lack of closure (Baldocchi, 2008) because such a correction relies on similarity assumptions that are not supported by low frequency spectra (Foken et al., 2011; Kidston et al., 2010; Mauder et al., 2007a; Ruppert et al., 2006), although we note that many watershed-level analyses demonstrate improved water budget closure when correcting $\lambda E$ for lack of energy balance closure (Barr et al., 2012; Jung et al., 2011; Twine et al., 2000). Our analysis cannot preclude effects due to fetch or forest canopy edges (Detto et al., 2008; Sogachev et al., 2008), which are difficult to ascertain using $250 \mathrm{~m}$ or $1 \mathrm{~km}$ MODIS products. The connection between the flux footprint and energy balance closure is discussed in Appendix B.

\subsection{Conclusions}

The flux community has made substantial advances in understanding the mechanisms underlying the energy balance closure problem (Foken et al., 2011; Leuning et al., 2012), but additional work needs to be done (Mahrt, 2010). However, assuming conservatively that the terms excluded from equation 1 comprise a couple to a few percentage points apiece, on average, then $C_{E B}$ is on the order of 0.95 or greater for many sites and vegetation types (namely grasslands, evergreen broadleaf forests and savannas) in version 2 of the FLUXNET database. These assumptions lend confidence to eddy covariance-based surface energy balance studies on long-term flux sums although further investigations into the energy balance closure problem are needed.

No surface flux campaign project (e.g. LITFASS-2003) has reported full energy balance closure to date (see Table 2 in Foken, 2008), suggesting that the same will hold for individual towers. The leading hypothesis from comprehensive surface flux investigations is that larger atmospheric motions, potentially driven by surface heterogeneity, are the principal explanation for lack of closure. The present study agrees that landscape-level heterogeneity is an important contributor to lack of energy balance closure from a data-driven perspective (Gray, 2009); $C_{E B, S}$ in globally-distributed flux towers is significantly related to landscape-level heterogeneity in land cover (via PFT) and characteristics (via EVI, Fig. 7). Models for $C_{E B, S}$ across the FLUXNET database cannot exclude $\sigma^{2}(E V I)$, landscape-level topographic variability, or $P$. The placement of future flux towers should be cognizant of the larger region beyond the immediate flux footprint.

The physical explanations behind the relationship between energy balance closure and landscape heterogeneity should be investigated mechanistically, for example using large eddy simulation or regional atmospheric modeling approaches (Badiya Roy and Avissar, 2002; Kanda et al., 2004; Steinfeld et al., 2007). A greater mechanistic understanding of flux transporting mechanisms and heat storage terms will add value to the water and energy flux observations in the FLUXNET database and, finally, bring closure to the energy balance closure problem.

\section{Acknowledgments}

We would first and foremost like to acknowledge the FLUXNET data providers and the organizers of the FLUXNET database. This work is an outcome of the La Thuile FLUXNET workshop 2007, which would not have been possible without the financial support provided by CarboEurope-IP, FAOGTOS-TCO, iLEAPS, Max Planck Institute for Biogeochemistry, National Science Foundation, University of Tuscia, and the U.S. Department of Energy. The Berkeley Water Center, Lawrence Berkeley National Laboratory, Microsoft Research eScience, Oak Ridge National Laboratory provided databasing and technical support. The AmeriFlux, Afriflux, AsiaFlux, CarboAfrica, CarboEuropeIP, ChinaFlux, FluxnetCanada, the Canadian Carbon Program, KoFlux, LBA, NECC, OzFlux, TCOS-Siberia, and USCCC networks provided data. Tristan Quaife provided the MATLAB code to download and organize MODIS data from the ORNL MODIS web service. Eva Falge contributed to the analyses in the Appendix. PS-O would like to acknowledge CARBORED. PCS acknowledges funding from the Marie Curie European Incoming International Fellowship (project number 237348, TSURF), the National Science Foundation ('Scaling ecosystem function: Novel Approaches from MaxEnt and Multiresolution', DBI \#1021095), and Montana State University. PCS would like to thank Hans-Peter Schmid and the Karlsruhe Institute of Technology for logistical support, Robert Bemis for creating the MATLAB code that followed the suggestions of Light and Bartlein (2004) for improved use of color in images, and Stefan Metzger, Andrew Richardson and LobsterFest participants, Eva Falge and Pierre Brender for helpful discussions about the manuscript.

\section{Appendix A.}

Table A1 details the FLUXNET sites used in this analysis.

\section{Appendix B. The relationship between flux footprints and energy balance closure}

It must be assumed that both the area surrounding a flux station (classified for example with satellite data) and the footprint climatology of a station have a significant influence on energy balance closure. Unfortunately, footprint information is only available for a few stations, although recent analyses have extended footprint analyses to entire flux networks (e.g. Chen et al., 2011, 2012). Göckede et al. (2008) performed a footprint classification for the European FLUXNET sites (i.e. the CarboEurope-IP sites) to quantify the contribution of the target area to the measured flux according to the footprint climatology. Site evaluations were performed by calculating the percentage of half-hourly measurements exceeding the threshold of $80 \%$ flux contribution from the target land cover type. No statistical relationship was found between relative energy balance closure and the percentage of half hourly measurements exceeding the threshold of $80 \%$ flux contribution from the target land area for three sites, using both the entire data set and data with a zenith angle $<50^{\circ}$ to incorporate only daytime values that may feature secondary circulations (data not shown). Only for four of twenty sites (DK-Sor, BE-Bra, DE-Tha and IT-Ren) were significant differences between the entire observational data set and data with a solar zenith angle $<50^{\circ}$ found.

The satellite pictures of the stations DK-Sor, BE-Bra, DE-Tha and IT-Ren (Fig. A1) demonstrate that each tower is in a nearly homogeneous area related to the turbulent eddy covariance flux footprint, but the larger landscape exhibits considerable 
Table A1

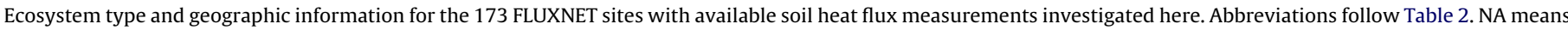

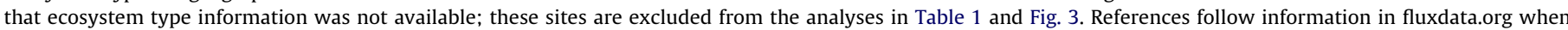
possible.

\begin{tabular}{|c|c|c|c|c|}
\hline Site & Veg. & Latitude & Longitude & Reference \\
\hline ATNeu & GRA & 47.11667 & 11.3175 & Wohlfahrt et al. (2008) \\
\hline AUFog & WET & -12.5425 & 131.307 & Guerschman et al. (2009) \\
\hline AUHow & SAV & -12.4943 & 131.152 & Hutley et al. (2000) \\
\hline AUTum & $\mathrm{EBF}$ & -35.6557 & 148.152 & Finnigan and Leuning (2000) \\
\hline AUWac & $\mathrm{EBF}$ & -37.429 & 145.187 & Beringer et al. (2006) \\
\hline BEBra & $\mathrm{MF}$ & 51.3092 & 4.52056 & de Pury and Ceulemans (1997) \\
\hline BEJal & $\mathrm{MF}$ & 50.5639 & 6.07333 & - \\
\hline BELon & CRO & 50.5522 & 4.74494 & Moureaux et al. (2006) \\
\hline BEVie & MF & 50.3055 & 5.99683 & Aubinet et al. (2001) \\
\hline BRBan & $\mathrm{EBF}$ & -9.82442 & -50.1591 & Borma et al. (2009) \\
\hline BRMa2 & EBF & -2.6091 & -60.2093 & - \\
\hline BRSa3 & EBF & -3.01803 & -54.9714 & Saleska et al. (2003) \\
\hline BRSp1 & SAV & -21.6195 & -47.6499 & Baker et al. (2004) \\
\hline BWMa1 & SAV & -19.9155 & 23.5605 & Veenendaal et al. (2004) \\
\hline CACa1 & ENF & 49.8672 & -125.334 & Morgenstern et al. (2004) \\
\hline CACa2 & ENF & 49.8705 & -125.291 & Humphreys et al. (2006) \\
\hline CACa3 & ENF & 49.5346 & -124.9 & Jassal et al. (2008) \\
\hline CAGro & MF & 48.2167 & -82.1556 & Pejam et al. (2006) \\
\hline CAMer & WET & 45.4094 & -75.5186 & Lafleur et al. (2003) \\
\hline CAOas & DBF & 53.6289 & -106.198 & Black et al. (1996) \\
\hline CAObs & ENF & 53.9872 & -105.118 & Jarvis et al. (1997) \\
\hline CAOjp & ENF & 53.9163 & -104.692 & Baldocchi et al. (1997) \\
\hline CAQcu & ENF & 49.2671 & -74.0365 & Giasson et al. (2006) \\
\hline CAQfo & ENF & 49.6925 & -74.3421 & Bergeron et al. (2007) \\
\hline CATP1 & ENF & 42.6609 & -80.5595 & Peichl and Arain (2007) \\
\hline САTP2 & ENF & 42.7744 & -80.4588 & Peichl and Arain (2007) \\
\hline САTP3 & ENF & 42.7068 & -80.3483 & Peichl and Arain (2007) \\
\hline CATP4 & ENF & 42.7098 & -80.3574 & Arain and Restrepo-Coupe (2005) \\
\hline CHOe1 & GRA & 47.2856 & 7.73214 & Ammann et al. (2007) \\
\hline CHOe2 & CRO & 47.2863 & 7.73433 & Kutsch et al. (2010) \\
\hline CNBed & $\mathrm{EBF}$ & 39.5306 & 116.252 & Liu et al. (2009) \\
\hline CNCha & $\mathrm{MF}$ & 42.4025 & 128.096 & Guan et al. (2006) \\
\hline CNDo1 & WET & 31.5167 & 121.961 & Yan et al. (2008) \\
\hline CNDo2 & WET & 31.5847 & 121.903 & Yan et al. (2008) \\
\hline CNDo3 & WET & 31.5169 & 121.972 & Yan et al. (2008) \\
\hline CNDu1 & CRO & 42.0456 & 116.671 & Zhang et al. (2007) \\
\hline CNDu2 & GRA & 42.0467 & 116.284 & Zhang et al. (2007) \\
\hline CNHaM & GRA & 37.37 & 101.18 & Fu et al. (2006) \\
\hline CNKu1 & EBF & 40.5383 & 108.694 & Wilske et al. (2009) \\
\hline CNKu2 & SHR & 40.3808 & 108.549 & Wilske et al. (2009) \\
\hline CNXfs & NA & 44.13417 & 116.3286 & Miao et al. (2009) \\
\hline CNXi1 & GRA & 43.54583 & 116.6778 & Chen et al. (2009) \\
\hline CNXi2 & GRA & 43.5544 & 116.671 & Wang et al. (2008) \\
\hline DEBay & ENF & 50.1419 & 11.8669 & Valentini et al. (2000) \\
\hline DEGeb & CRO & 51.1001 & 10.9143 & Anthoni et al. (2004a) \\
\hline DEGri & GRA & 50.9495 & 13.5125 & Owen et al. (2007) \\
\hline DEHai & DBF & 51.0793 & 10.452 & Knohl et al. (2003) \\
\hline DEHar & ENF & 47.9344 & 7.601 & Bernhofer et al. (1996) \\
\hline DEKli & CRO & 50.8929 & 13.5225 & Owen et al. (2007) \\
\hline DEMeh & GRA & 51.2753 & 10.6555 & Don et al. (2009) \\
\hline DETha & ENF & 50.9636 & 13.5669 & Bernhofer et al. (2003) \\
\hline DEWet & ENF & 50.4535 & 11.4575 & Anthoni et al. (2004b) \\
\hline DKFou & CRO & 56.4842 & 9.58722 & Soegaard et al. (2003) \\
\hline DKLva & GRA & 55.6833 & 12.0833 & Soussana et al. (2007) \\
\hline DKSor & DBF & 55.4869 & 11.6458 & Pilegaard et al. (2001) \\
\hline ESES1 & ENF & 39.346 & -0.31881 & Sanz et al. (2004) \\
\hline ESES2 & CRO & 39.2755 & -0.31522 & - \\
\hline ESLJu & SHR & 36.9282 & -2.75047 & Serrano-Ortiz et al. (2007) \\
\hline ESLMa & SAV & 39.9415 & -5.77336 & - \\
\hline ESVDA & GRA & 42.1522 & 1.4485 & Gilmanov et al. (2007) \\
\hline FIHyy & ENF & 61.8474 & 24.2948 & Suni et al. (2003) \\
\hline FIKaa & WET & 69.1407 & 27.295 & Aurela et al. (2002) \\
\hline FISod & ENF & 67.3619 & 26.6378 & Thum et al. (2007) \\
\hline FRAur & CRO & 43.5494 & 1.10778 & Beziat et al. (2009) \\
\hline FRGri & CRO & 48.844 & 1.95243 & Laville et al. (1999) \\
\hline FRHes & $\mathrm{DBF}$ & 48.6742 & 7.06462 & Granier et al. (2000) \\
\hline FRLam & CRO & 43.4933 & 1.23722 & Beziat et al. (2009) \\
\hline FRLBr & ENF & 44.7171 & -0.7693 & Berbigier et al. (2001) \\
\hline FRPue & EBF & 43.7414 & 3.59583 & Rambal et al. (2004) \\
\hline HUBug & GRA & 46.6911 & 19.6013 & Nagy et al. (2005) \\
\hline HUMat & GRA & 47.8469 & 19.726 & Nagy et al. (2005) \\
\hline IECa1 & CRO & 52.8588 & -6.91814 & Black et al. (2006) \\
\hline IEDri & GRA & 51.9867 & -8.75181 & Peichl et al. (2011) \\
\hline ILYat & ENF & 31.345 & 35.0515 & Grunzweig et al. (2003) \\
\hline
\end{tabular}


Table A1 (Continued)

\begin{tabular}{|c|c|c|c|c|}
\hline Site & Veg. & Latitude & Longitude & Reference \\
\hline ISGun & DBF & 63.8333 & -20.2167 & Falge et al. (2002) \\
\hline ITAmp & GRA & 41.9041 & 13.6052 & Wohlfahrt et al. (2008) \\
\hline ITBCi & CRO & 40.5238 & 14.9574 & Reichstein et al. (2003) \\
\hline ITCas & CRO & 45.06285 & 8.668539 & Skiba et al. (2009) \\
\hline ITCol & DBF & 41.8494 & 13.5881 & Valentini et al. (1996) \\
\hline ITCpz & EBF & 41.7052 & 12.3761 & Tirone et al. (2003) \\
\hline ITLav & ENF & 45.9553 & 11.2812 & Cescatti and Marcolla (2004) \\
\hline ITLec & EBF & 43.3046 & 11.2706 & Maselli et al. (2009) \\
\hline ITLMa & GRA & 45.5813 & 7.15463 & Maselli et al. (2006) \\
\hline ITMal & GRA & 46.1167 & 11.7028 & Flechard et al. (2007) \\
\hline ITMBo & GRA & 46.0156 & 11.0467 & Marcolla et al. (2011) \\
\hline ITNoe & SHR & 40.606 & 8.151 & Reichstein et al. (2002) \\
\hline ITNon & DBF & 44.6898 & 11.0887 & Nardino et al. (2002) \\
\hline ITPT1 & DBF & 45.2009 & 9.06104 & Migliavacca et al. (2009) \\
\hline ITRen & ENF & 46.5878 & 11.4347 & Marcolla et al. (2005) \\
\hline ITRo1 & DBF & 42.4081 & 11.93 & Rey et al. (2002) \\
\hline ITRo2 & DBF & 42.3903 & 11.9209 & Tedeschi et al. (2006) \\
\hline ITSRo & ENF & 43.72786 & 10.28444 & Chiesi et al. (2005) \\
\hline JPMas & CRO & 36.05397 & 140.0269 & Saito et al. (2005) \\
\hline JPTom & MF & 42.7395 & 141.5149 & Hirano et al. (2003) \\
\hline KRHnm & NA & 34.55 & 126.57 & Lee et al. (2003) \\
\hline KRKw1 & $\mathrm{MF}$ & 37.7486 & 127.163 & Kim et al. (2006) \\
\hline NLCa1 & GRA & 51.971 & 4.927 & Jacobs et al. (2007) \\
\hline NLLan & CRO & 51.9536 & 4.9029 & Moors et al. (2010) \\
\hline NLLoo & ENF & 52.1679 & 5.74396 & Dolman et al. (2002) \\
\hline NLLut & CRO & 53.3989 & 6.356 & Moors et al. (2010) \\
\hline PLWet & WET & 52.7622 & 16.3094 & Chojnicki et al. (2007) \\
\hline PTMi2 & GRA & 38.4765 & -8.02455 & Pereira et al. (2007) \\
\hline RUChe & WET & 68.6147 & 161.339 & Corradi et al. (2005) \\
\hline RUFyo & ENF & 56.46167 & 32.92389 & Kurbatova et al. (2008) \\
\hline RUZot & ENF & 60.8008 & 89.3508 & Kurbatova et al. (2002) \\
\hline SEAbi & DBF & 68.36239 & 18.79475 & Christensen et al. (2007) \\
\hline SEFaj & WET & 56.2655 & 13.5535 & Lund et al. (2007) \\
\hline SEFla & ENF & 64.1128 & 19.4569 & Valentini et al. (2000) \\
\hline SENor & ENF & 60.0865 & 17.4795 & Lagergren et al. (2008) \\
\hline SESk1 & ENF & 60.125 & 17.9181 & Gioli et al. (2004) \\
\hline SKTat & ENF & 49.1208 & 20.1635 & Matese et al. (2008) \\
\hline UKAMo & WET & 55.7917 & -3.23889 & Hargreaves et al. (2003) \\
\hline UKEBu & GRA & 55.866 & -3.20578 & Famulari et al. (2004) \\
\hline UKESa & CRO & 55.90694 & -2.85861 & Hendricks Franssen et al. (2010) \\
\hline UKGri & ENF & 56.60722 & -3.79806 & Medlyn et al. (2005) \\
\hline UKHam & DBF & 51.15353 & -0.8583 & Wilkinson et al. (2012) \\
\hline UKHer & CRO & 51.7838 & -0.47608 & - \\
\hline USARb & GRA & 35.5497 & -98.0402 & Fischer et al. (2007) \\
\hline USARc & GRA & 35.54649 & -98.04 & Fischer et al. (2007) \\
\hline USARM & CRO & 36.6058 & -97.4888 & Fischer et al. (2007) \\
\hline USAtq & WET & 70.4696 & -157.409 & - \\
\hline USAud & GRA & 31.5907 & -110.51 & - \\
\hline USBkg & GRA & 44.3453 & -96.8362 & Gilmanov et al. (2005) \\
\hline USBlo & ENF & 38.8952 & -120.6328 & Goldstein et al. (2000) \\
\hline USBn1 & ENF & 63.9198 & -145.378 & Liu et al. (2005) \\
\hline USBn2 & DBF & 63.9198 & -145.378 & Liu et al. (2005) \\
\hline USBn3 & SHR & 63.9227 & -145.744 & Liu et al. (2005) \\
\hline USBo1 & CRO & 40.0062 & -88.2904 & Meyers and Hollinger (2004) \\
\hline USBo2 & CRO & 40.009 & -88.29 & Meyers and Hollinger (2004) \\
\hline USBrw & WET & 71.3225 & -156.6259 & Vourlitis and Oechel (1999) \\
\hline USCaV & GRA & 39.0633 & -79.4208 & Owen et al. (2007) \\
\hline USFmf & ENF & 35.1426 & -111.7273 & Dore et al. (2008) \\
\hline USFPe & GRA & 48.3077 & -105.1019 & Gilmanov et al. (2005) \\
\hline USFR2 & SAV & 29.9495 & -97.9962 & Heinsch et al. (2004) \\
\hline USFuf & ENF & 35.089 & -111.762 & Dore et al. (2008) \\
\hline USFwf & GRA & 35.4454 & -111.7718 & Dore et al. (2008) \\
\hline USGoo & GRA & 34.2547 & -89.8735 & Wilson and Meyers (2007) \\
\hline USHo1 & ENF & 45.2041 & -68.7402 & Hollinger et al. (1999) \\
\hline USIB1 & CRO & 41.8593 & -88.2227 & Allison et al. (2005) \\
\hline USIB2 & GRA & 41.8406 & -88.241 & Allison et al. (2005) \\
\hline USIvo & WET & 68.4865 & -155.75 & Epstein et al. (2004) \\
\hline USKS2 & SHR & 28.6086 & -80.6715 & Powell et al. (2006) \\
\hline USLos & DBF & 46.0827 & -89.9792 & Desai et al. (2008) \\
\hline USMe1 & ENF & 44.5794 & -121.5 & Law et al. (2001) \\
\hline USMe2 & ENF & 44.4523 & -121.5574 & Campbell et al. (2004) \\
\hline USMe3 & ENF & 44.3154 & -121.6078 & Vickers et al. (2009) \\
\hline USMe4 & ENF & 44.4992 & -121.6224 & Irvine et al. (2004) \\
\hline USMMS & DBF & 39.3231 & -86.4131 & Schmid et al. (2000) \\
\hline USMOz & DBF & 38.7441 & -92.2 & Gu et al. (2006) \\
\hline USNC1 & SHR & 35.8115 & -76.7115 & Noormets et al. (2010) \\
\hline USNC2 & ENF & 35.8031 & -76.6679 & Domec et al. (2009) \\
\hline
\end{tabular}


Table A1 (Continued)

\begin{tabular}{|c|c|c|c|c|}
\hline Site & Veg. & Latitude & Longitude & Reference \\
\hline USNe1 & CRO & 41.1651 & -96.4766 & Verma et al. (2005) \\
\hline USNe2 & CRO & 41.1649 & -96.4701 & Verma et al. (2005) \\
\hline USNe3 & CRO & 41.1797 & -96.4397 & Verma et al. (2005) \\
\hline USNR1 & ENF & 40.0329 & -105.546 & Monson et al. (2002) \\
\hline USOho & DBF & 41.5545 & -83.8438 & DeForest et al. (2006) \\
\hline USSO2 & SHR & 33.3739 & -116.6229 & Lipson et al. (2005) \\
\hline USSO3 & SHR & 33.3772 & -116.6227 & Lipson et al. (2005) \\
\hline USSO4 & SHR & 33.3844 & -116.6403 & Lipson et al. (2005) \\
\hline USSP1 & ENF & 29.7381 & -82.2188 & Clark et al. (1999) \\
\hline USSP2 & ENF & 29.7648 & -82.2448 & Clark et al. (1999) \\
\hline USSP3 & ENF & 29.7548 & -82.1633 & Clark et al. (1999) \\
\hline USSRM & SAV & 31.8214 & -110.866 & Scott et al. (2009) \\
\hline USSyv & MF & 46.242 & -89.3477 & Desai et al. (2005) \\
\hline USTon & SAV & 38.4316 & -120.966 & Ma et al. (2007) \\
\hline USVar & GRA & 38.4133 & -120.9507 & Ma et al. (2007) \\
\hline USWBW & DBF & 35.9588 & -84.2874 & Verma et al. (1986) \\
\hline USWCr & DBF & 45.8059 & -90.0799 & Cook et al. (2004) \\
\hline USWi1 & DBF & 46.7305 & -91.2329 & Noormets et al. (2007) \\
\hline USWi2 & ENF & 46.6869 & -91.1528 & Noormets et al. (2007) \\
\hline USWi8 & DBF & 46.7223 & -91.2524 & Noormets et al. (2007) \\
\hline USWkg & GRA & 31.7365 & -109.942 & Scott et al. (2010) \\
\hline USWrc & ENF & 45.8205 & -121.952 & Chen et al. (2002) \\
\hline
\end{tabular}

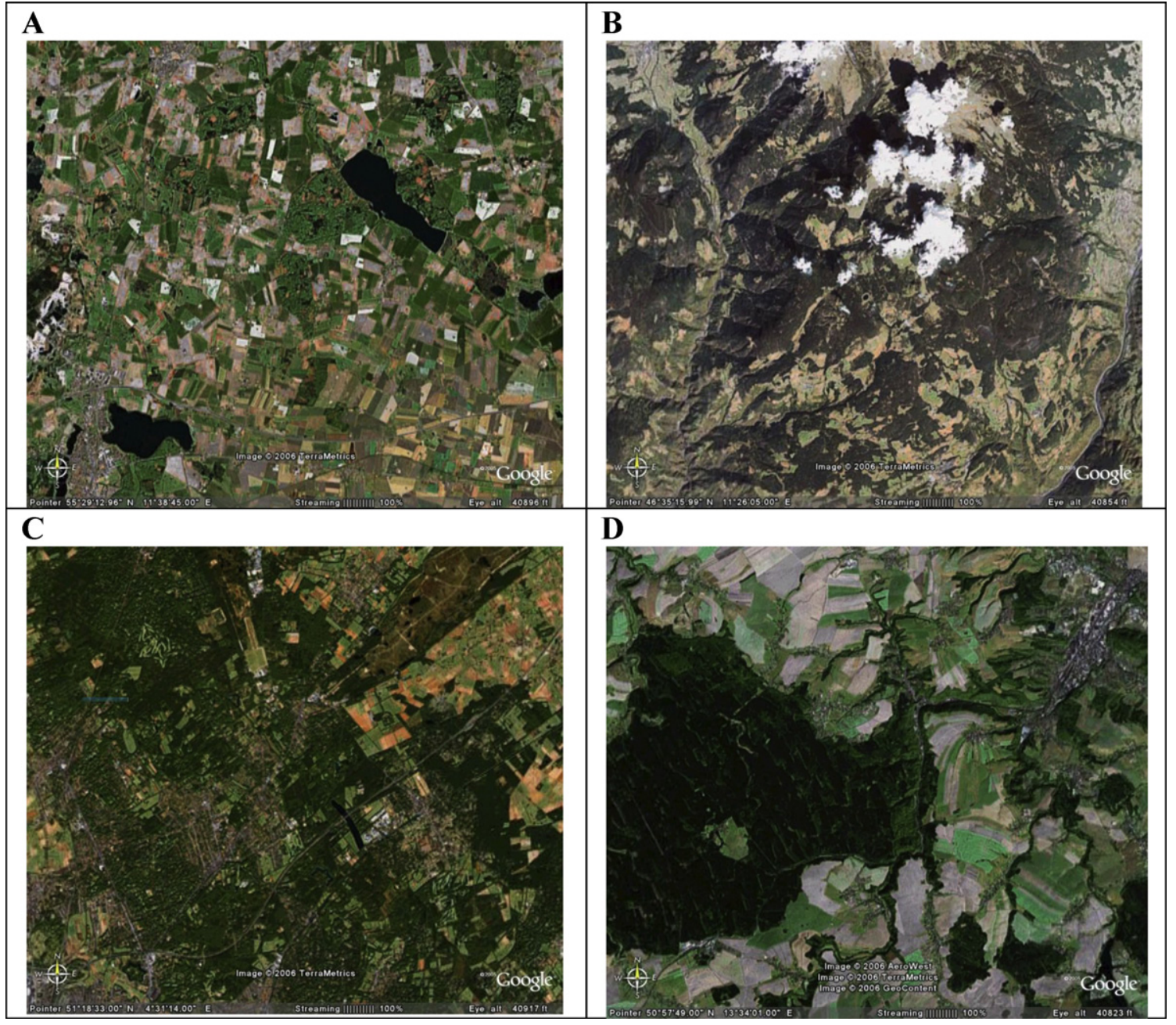

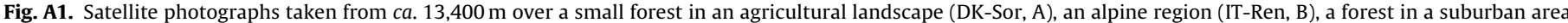

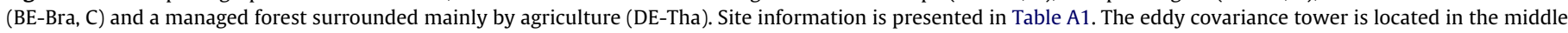
of all images, which are approximately $20 \mathrm{~km}$ along the east-west axis. 
variability. The surface energy balance is likely affected on a scale of $c a .20 \mathrm{~km} \times 20 \mathrm{~km}$, possibly as a result of secondary circulations, during daytime periods. On the other hand, for the station DK-Sor, the energy balance closure is better for daytime data, when the small forest area tends to lie within the flux footprint.

\section{References}

Allison, V.J., Miller, R.M., Jastrow, J.D., Matamala, R., Zak, D.R., 2005. Changes in soil microbial community structure in a tallgrass prairie chronosequence. Soil Sci. Soc. Am. J. 69 (5), 1412-1421.

Ammann, C., Flechard, C.R., Leifeld, J., Neftel, A., Fuhrer, J., 2007. The carbon budget of newly established temperate grassland depends on management intensity. Agric. Ecosyst. Environ. 121, 5-20.

Anthoni, P.M., Freibauer, A., Kolle, O., Schulze, E.-D., 2004a. Winter wheat carbon exchange in Thuringia, Germany. Agric. Forest Meteorol. 121 (1-2), 55-67.

Anthoni, P.M., Knohl, A., Rebmann, C., Freibauer, A., Mund, M., Ziegler, W., Kolle, O., Schulze, E.D., 2004b. Forest and agricultural land-use-dependent $\mathrm{CO}_{2}$ exchange in Thuringia, Germany. Global Change Biol. 10 (12), 2005-2019.

Arain, M.A., Restrepo-Coupe, N., 2005. Net ecosystem production in a temperate pine plantation in southeastern Canada. Agric. Forest Meteorol. 128 (3-4), 223-241.

Aubinet, M., Chermanne, B., Vandenhaute, M., Longdoz, B., Yernaux, M., Laitat, E., 2001. Long term carbon dioxide exchange above a mixed forest in the Belgian Ardennes. Agric. Forest Meteorol. 108 (4), 293-315.

Aubinet, M., Feigenwinter, C., Heinesch, B., Bernhofer, C., Canepa, E., Lindroth, A, Montagnani, L., Rebmann, C., Sedlak, P., Gorsel van, E., 2010. Direct advection measurements do not help to solve the night-time $\mathrm{CO}_{2}$ closure problem: evidence from three different forests. Agric. Forest Meteorol. 150 (5), 655-664.

Aubinet, M., Grelle, A., Ibrom, A., Rannik, Ü., Moncrieff, J., Foken, T., Kowalski, A.S., Martin, P.H., Berbigier, P., Bernhofer, C., Clement, R., Elbers, J., Granier, A., Grunwald, T., Morgenstern, K., Pilegaard, K., Rebmann, C., Snijders, W., Valentini, R., Vesala, T., 2000. Estimates of the annual net carbon and water exchange of forests: the EUROFLUX methodology. Adv. Ecol. Res. 30, 113-175.

Aurela, M., Laurila, T., Tuovinen, J.P., 2002. Annual $\mathrm{CO}_{2}$ balance of a subarctic fen in northern Europe: importance of the wintertime efflux. J. Geophys. Res.Atmosph. 107 (D21), 4607.

Badiya Roy, S., Avissar, R., 2002. Impact of land use/land cover change on regional hydrometeorology in Amazonia. J. Geophys. Res. 107 (D20, 8037), http://dx.doi.org/10.1029/2000JD000266.

Baidya Roy, S., Weaver, C.P., Nolan, D.S., Avissar, R., 2003. A preferred scale for landscape forced mesoscale circulations? J. Geophys. Res. 108 (D22), 8854.

Baker, T.R., Phillips, O.L., Malhi, Y., Almeida, S., Arroyo, L., Di Fiore, A., Erwin, T., Killeen, T.J., Laurance, S.G., Laurance, W.F., Lewis, S.L., Lloyd, J., Monteagudo, A., Neill, D.A., Patiño, S., Pitman, N.C.A., Silva, J.N.M., Vásquez Martínez, R., 2004. Variation in wood density determines spatial patterns in Amazonian forest biomass. Global Change Biol. 10 (5), 545-562.

Baldocchi, D., Falge, E., Gu, L.H., Olson, R., Hollinger, D., Running, S., Anthoni, P., Bernhofer, C., Davis, K., Evans, R., Fuentes, J., Goldstein, A., Katul, G., Law, B., Lee, X.H., Malhi, Y., Meyers, T., Munger, W., Oechel, W., Paw, U.K.T., Pilegaard, K., Schmid, H.P., Valentini, R., Verma, S., Vesala, T., Wilson, K., Wofsy, S., 2001 FLUXNET: A new tool to study the temporal and spatial variability of ecosystemscale carbon dioxide, water vapor, and energy flux densities. Bull. Am. Meteorol. Soc. 82 (11), 2415-2434.

Baldocchi, D.D., 2008. 'Breathing' of the terrestrial biosphere: Lessons learned from a global network of carbon dioxide flux measurements systems. Aust. J. Bot. 56, $1-26$.

Baldocchi, D.D., Vogel, C.A., Hall, B., 1997. Seasonal variation of carbon dioxide exchange rates above and below a boreal jack pine forest. Agric. Forest Meteorol. $83(1-2), 147-170$

Barr, A.G., Morgenstern, K., Black, T.A., McCaughey, J.H., Nesic, Z., 2006. Surface energy balance closure by the eddy covariance method above three boreal forest stands and implications for the measurement of $\mathrm{CO}_{2}$ flux. Agric. Forest Meteorol. $140,322-337$

Barr, A.G., van der Kamp, G., Black, T.A., McCaughey, J.H., Nesic, Z., 2012. Energy balance closure at the BERMS flux towers in relation to the water balance of the White Gull Creek watershed 1999-2009. Agric. Forest Meteorol. 153, 3-13.

Berbigier, P., Bonnefond, J.-M., Mellmann, P., 2001. $\mathrm{CO}_{2}$ and water vapour fluxes for 2 years above Euroflux forest site. Agric. Forest Meteorol. 108 (3), 183-197.

Bergeron, O., Margolis, H.A., Black, T.A., Coursolle, C., Dunn, A.L., Barr, A.G., Wofsy, S.C., 2007. Comparison of carbon dioxide fluxes over three boreal black spruce forests in Canada. Global Change Biol. 13 (1), 89-107.

Beringer, J., Hutley, L., Kilinc, M., McGuire, A.D., McHugh, I., 2006. Water, energy and carbon fluxes from the world's tallest anigosperm (Eucalyptus regnans) at Wallaby Creek, south-eastern Australia. In: International Geographical Union Conference "Regional Responses to Global Changes: A View from the Antipodes", Brisbane, Australia.

Bernhofer, C., Aubinet, M., Clement, R., Grelle, A., Grunwald, T., Ibrom, A., Jarvis, P., Rebmann, C., Schulze, E.-D., Tenhunen, J., 2003. Spruce forests (Norway and Sitka Spruce, including Douglas Fir): carbon and water fluxes and balances, ecological and ecophysiological determinants. In: Valentini, R. (Ed.), Fluxes of Carbon, Water and Energy of European Forests. Springer-Verlag, Berlin.

Bernhofer, C., Gay, L.W., Granier, A., Joss, U., Kessler, A., Köstner, B., Siegwolf, R., Tenhunen, J.D., Vogt, R., 1996. The HartX-synthesis: an experimental approach to water and carbon exchange of a Scots pine plantation. Theor. Appl. Climatol. 53 (1), 173-183.

Beyrich, F., Richter, S.H., Weisensee, U., Kohsiek, W., Lohse, H., DeBruin, A.R., Foken, T., Göckede, M., Berger, F.H., Vogt, R., Batchvarova, E., 2002. Experimental determination of turbulent fluxes over the heterogeneous LITFASS area: selected results from the LITFASS-98 experiment. Theor. Appl. Climatol. 73, 19-34.

Beziat, P., Ceschia, E., Dedieu, G., 2009. Carbon balance of a three crop succession over two cropland sites in South West France. Agric. Forest Meteorol. 149 (10), 1628-1645

Black, K., Davis, P., Lynch, P., Jones, M., McGettigan, M., Osborne, B., 2006. Long-term trends in solar irradiance in Ireland and their potential effects on gross primary productivity. Agric. Forest Meteorol. 141 (2-4), 118-132.

Black, T.A., Den Hartog, G., Neumann, H.H., Blanken, P.D., Yang, P.C., Russell, C., Nesic, Z., Lee, X., Chen, S.G., Staebler, R., Novak, M.D., 1996. Annual cycles of water vapour and carbon dioxide fluxes in and above a boreal aspen forest. Global Change Biol. 2 (3), 219-229.

Borma, L.S., da Rocha, H.R., Cabral, O.M., von Randow, C., Collicchio, E., Kurzatkowski, D., Brugger, P.J., Freitas, H., Tannus, R., Oliveira, L., RennÛ, C.D., Artaxo, P., 2009. Atmosphere and hydrological controls of the evapotranspiration over a floodplain forest in the Bananal Island region, Amazonia. J. Geophys. Res. 114 (G1) G01003.

Botev, Z.I., Grotowski, J.F., Kroese, D.P., 2010. Kernel density estimation via diffusion. Ann. Statist. 38, 2916-2957.

Brotzke, J.A., Duchon, C.E., 2000. A field comparison among a domeless net radiometer, two four-component net radiometers, and a domed net radiometer. J. Atmosph. Oceanic Technol. 17, 1569-1582.

Burba, G.G., McDermitt, D.K., Grelle, A., Anderson, D.J., Xu, L., 2008. Addressing the influence of instrument surface heat exchange on the measurements of $\mathrm{CO}_{2}$ flux from open-path gas analyzers. Global Change Biol. 14, 1-23.

Campbell, J.L., Sun, O.J., Law, B.E., 2004. Supply-side controls on soil respiration among Oregon forests. Global Change Biol. 10 (11), 1857-1869.

Cava, D., Contini, D., Donateo, A., Martano, P., 2008. Analysis of short-term closure of the surface energy balance above short vegetation. Agric. Forest Meteorol. 148 (1), 82-93.

Cescatti, A., Marcolla, B., 2004. Drag coefficient and turbulence intensity in conifer canopies. Agric. Forest Meteorol. 121 (3-4), 197-206.

Chen, B., Coops, N.C., Fu, D., Margolis, H.A., Amiro, B.D., Barr, A.G., Black, T.A., Arain M.A., Bourque, C.P.A., Flanagan, L.B., Lafleur, P.M., McCaughey, J.H., Wofsy, S.C. 2011. Assessing eddy-covariance flux tower location bias across the FluxnetCanada research network based on remote sensing and footprint modelling. Agric. Forest Meteorol. 151 (1), 87-100.

Chen, B., Coops, N.C., Fu, D., Margolis, H.A., Amiro, B.D., Black, T.A., Arain, M.A., Barr, A.G., Bourque, C.P.A., Flanagan, L.B., Lafleur, P.M., McCaughey, J.H., Wofsy, S.C., 2012. Characterizing spatial representativeness of flux tower eddy-covariance measurements across the Canadian Carbon Program Network using remote sensing and footprint analysis. Remote Sens. Environ. 124 (0), 742-755.

Chen, J., Falk, M., Euskirchen, E., Paw, n.U., Suchanek, K.T., Ustin, T.H., Bond, S.L., Brosofske, B.J., Phillips, K.D., Bi, N.R., 2002. Biophysical controls of carbon flows in three successional Douglas-fir stands based on eddy-covariance measurements. Tree Physiol. 22 (2-3), 169-177.

Chen, S., Chen, J., Lin, G., Zhang, W., Miao, H., Wei, L., Huang, J., Han, X., 2009. Energy balance and partition in Inner Mongolia steppe ecosystems with different land use types. Agric. Forest Meteorol. 149 (11), 1800-1809.

Chiesi, M., Maselli, F., Bindi, M., Fibbi, L., Cherubini, P., Arlotta, E., Tirone, G., Matteucci, G., Seufert, G., 2005. Modelling carbon budget of Mediterranean forests using ground and remote sensing measurements. Agric. Forest Meteorol. 135 (1-4), 22-34.

Chojnicki, B.H., Urbaniak, M., Jozefczyk, D., Augustin, J., Olejnik, J., 2007. Measurements of gas and heat fluxes at Rzecin wetland. In: Okruszko, T., Maltby, E. Szatylowicz, J., Miroslow-Swiakek, D., Kotowski, W. (Eds.), Wetlands: Monitoring, Modelling and Management. Taylor \& Francis Group, London, pp. $125-131$.

Christensen, T.R., Johansson, T., Olsrud, M., Ström, L., Lindroth, A., Mastepanov, M. Malmer, N., Friborg, T., Crill, P., Callaghan, T.V., 2007. A catchment-scale carbon and greenhouse gas budget of a subarctic landscape. Philos. Trans. R. Soc. A 365 1643-1656.

Clark, K.L., Gholz, H.L., Moncrieff, J.B., Cropley, F., Loescher, H.W., 1999, Environmental controls over net exchanges of carbon dioxide from contrasting florida ecosystems. Ecol. Appl. 9 (3), 936-948.

Clement, R.J., Burba, G.G., Grelle, A., Anderson, D.J., Moncrieff, J.B., 2009. Improved trace gas flux estimation through IRGA sampling optimization. Agric. Forest Meteorol. 149 (3-4), 623-638.

Cook, B.D., Davis, K.J., Wang, W., Desai, A.R., Berger, B.W., Teclaw, R.M., Martin, J.M. Bolstad, P.V., Bakwin, P., Yi, C., Heilman, W., 2004. Carbon exchange and venting anomalies in an upland deciduous forest in norhern Wisconsin, USA. Agric. Forest Meteorol. 126, 271-295.

Corradi, C., Kolle, O., Walter, K., Zimov, S.A., Schulze, E.D., 2005. Carbon dioxide and methane exchange of a north-east Siberian tussock tundra. Global Change Biol. 11 (11), 1910-1925.

de Pury, D.G.G., Ceulemans, R., 1997. Scaling-up carbon fluxes from leaves to stands in a patchy coniferous/deciduous forest. In: Mohren, G.M.J. (Ed.), Impacts of Global Change on Tree Physiology and Forest Ecosystems. Kluwer Academic Publishers, Dordrecht, pp. 263-272.

DeForest, J., Noormets, A., McNulty, S., Sun, G., Tenney, G., Chen, J., 2006. Phenophases alter the soil respiration-temperature relationship in an oak-dominated forest. Int. J. Biometeorol. 51 (2), 135-144. 
Dellwik, E., Mann, J., Bingöl, F., 2010a. Flow tilt angles near forest edges-Part 1: Sonic anemometry. Biogeosciences 7, 1745-1757.

Dellwik, E., Mann, J., Larsen, K.S., 2010b. Flow tilt angles near forest edges-Part 2: Lidar anemometry. Biogeosciences 7, 1759-1768.

Desai, A.R., Bolstad, P.V., Cook, B.D., Davis, K.J., Carey, E.V., 2005. Comparing net ecosystem exchange of carbon dioxide between an old-growth and mature forest in the upper Midwest, USA. Agric. Forest Meteorol. 128, 33-55.

Desai, A.R., Richardson, A.D., Moffat, A.M., Kattge, J., Hollinger, D.Y., Barr, A.G., Falge, E., Noormets, A., Papale, D., Reichstein, M., Stauch, V.J., 2008. Cross-site evaluation of eddy covariance GPP and RE decomposition techniques. Agric. Forest Meteorol. 148, 821-838.

Detto, M., Katul, G.G., Siqueira, M.B.S., Juang, J.-Y., Stoy, P.C., 2008. The structure of turbulence near a tall forest edge: the backward-facing step flow analogy revisited. Ecol. Appl. 18, 1420-1435.

Dolman, A.J., Moors, E.J., Elbers, J.A., 2002. The carbon uptake of a mid latitude pine forest growing on sandy soil. Agric. Forest Meteorol. 111 (3), 157-170.

Domec, J.-C., Noormets, A., King, J.S., Sun, G.E., McNulty, S.G., Gavazzi, M.J., Boggs, J.L., Treasure, E.A., 2009. Decoupling the influence of leaf and root hydraulic conductances on stomatal conductance and its sensitivity to vapour pressure deficit as soil dries in a drained loblolly pine plantation. Plant Cell Environ. 32 (8), 980-991.

Don, A., Rebmann, C., Kolle, O., Scherer-Lorenzen, M., Schulze, E.-D., 2009. Impact of afforestation-associated management changes on the carbon balance of grassland. Global Change Biol. 15 (8), 1990-2002.

Dore, S., Kolb, T.E., Montes-Helu, M.C., Sullivan, B.W., Winslow, W.D., Hart, S.C., Kaye, J.P., Koch, G.W., Hungate, B.A., 2008. Long-term impact of a stand-replacing fire on ecosystem $\mathrm{CO}_{2}$ exchange of a ponderosa pine forest. Global Change Biol. 14, 1801-1820.

Epstein, H.E., Calef, M.P., Walker, M.D., Chapin, F.S.I., Starfield, A.M., 2004. Detecting changes in arctic tundra plant communities in response to warming over decadal time scales. Global Change Biol. 10 (8), 1325-1334.

Etzold, S., Buchmann, N., Eugster, W., 2010. Contribution of advection to the carbon budget measured by eddy covariance at a steep mountain slope forest in Switzerland. Biogeosciences 8, 2461-2475.

Falge, E., Baldocchi, D., Olson, R., Anthoni, P., Aubinet, M., Bernhofer, C., Burba, G., Ceulemans, G., Clement, R., Dolman, H., Granier, A., Gross, P., Grunwald, T., Hollinger, D., Jensen, N.O., Katul, G., Keronen, P., Kowalski, A., Lai, C.T., Law, B.E., Meyers, T., Moncrieff, J., Moors, E., Munger, J.W., Pilegaard, K., Rannik, U., Rebmann, C., Suyker, A., Tenhunen, J., Tu, K., Verma, S., Vesala, T., Wilson, K., Wofsy, S., 2001. Gap filling strategies for long term energy flux data sets. Agric. Forest Meteorol. 107 (1), 71-77.

Falge, E., Baldocchi, D., Tenhunen, J., Aubinet, M., Bakwin, P., Berbigier, P., Bernhofer, C., Burba, G., Clement, R., Davis, K.J., Elbers, J.A., Goldstein, A.H., Grelle, A., Granier, A., Guomundsson, J., Hollinger, D., Kowalski, A.S., Katul, G., Law, B.E., Malhi, Y., Meyers, T., Monson, R.K., Munger, J.W., Oechel, W., Paw, K.T., Pilegaard, K., Rannik, U., Rebmann, C., Suyker, A., Valentini, R., Wilson, K., Wofsy, S., 2002. Seasonality of ecosystem respiration and gross primary production as derived from FLUXNET measurements. Agric. Forest Meteorol. 113 (1-4), 53-74.

Famulari, D., Fowler, D., Hargreaves, K., Milford, C., Nemitz, E., Sutton, M.A., Weston, K., 2004. Measuring eddy covariance fluxes of ammonia using tunable diode laser absorption spectroscopy. Water, Air, Soil Pollut.: Focus 4 (6), 151-158.

Finnigan, J.J., Clement, R., Malhi, Y., Leuning, R., Cleugh, H.A., 2003. A re-evaluation of long-term flux measurement techniques Part I: averaging and coordinate rotation. Boundary-Layer Meteorol. 107, 1-48.

Finnigan, J.J., Leuning, R., 2000. Long term flux measurements-coordinate systems and averaging. In: Proceedings of the International Workshop for Advanced Flux Network and Flux Evaluation, Center for Global Environmental Research, National Institute for Environmental Studies, Japan, Hokkaido, Japan, pp. 51-56.

Fischer, M.L., Billesbach, D.P., Berry, J.A., Riley, W.J. Torn, M.S., 2007. Spatiotemporal variations in growing season exchanges of $\mathrm{CO}_{2}, \mathrm{H}_{2} \mathrm{O}$, and sensible heat in agricultural fields of the Southern Great Plains. Earth Interact. 11 (17), 1-21.

Flechard, C.R., Ambus, P., Skiba, U., Rees, R.M., Hensen, A., van Amstel, A., Dasselaar, A.v.d.P.-v., Soussana, J.F., Jones, M., Clifton-Brown, J., Raschi, A., Horvath, L., Neftel, A., Jocher, M., Ammann, C., Leifeld, J., Fuhrer, J., Calanca, P., Thalman, E., Pilegaard, K., Di Marco, C., Campbell, C., Nemitz, E., Hargreaves, K.J., Levy, P.E., Ball, B.C., Jones, S.K., van de Bulk, W.C.M., Groot, T., Blom, M., Domingues, R., Kasper, G., Allard, V., Ceschia, E., Cellier, P., Laville, P., Henault, C., Bizouard, F., Abdalla, M., Williams, M., Baronti, S., Berretti, F., Grosz, B., 2007. Effects of climate and management intensity on nitrous oxide emissions in grassland systems across Europe. Agric. Ecosyst. Environ. 121 (1-2), 135-152.

Foken, T., 1998. Ergebnisse des LINEX-97/1 Experimentes. Deutscher Wetterdienst, Forschung und Entwicklung Arbeitsergebnisse, 53.

Foken, T., 2008. The energy balance closure problem: an overview. Ecol. Appl. 18 (6), 1351-1367.

Foken, T., Aubinet, M., Finnigan, J.J., Leclerc, M.Y., Mauder, M., Paw U, K.T., 2011. Results of a panel discussion about the energy balance closure correction for trace gases. Bull. Am. Meteorol. Soc. 92, ES13-ES18.

Foken, T., Jegede, O.O., Weisensee, U., Richter, S.H., Handorf, D., Görsdorf, U., Vogel, G., Schubert, U., Kirzel, H.-J., Thiermann, V., 1997. Results of the LINEX-96/2 experiment. Deutscher Wetterdienst, Forschung und Entwicklung, 48.

Foken, T., Wimmer, F., Mauder, M., Thomas, C., Liebethal, C., 2006. Some aspects of the energy balance closure problem. Atmosph. Chem. Phys. 6, 4395-4402.

Fu, Y.-L., Yu, G.-R., Sun, X.-M., Li, Y.-N., Wen, X.-F., Zhang, L.-M., Li, Z.-Q., Zhao, L., Hao, Y.-B., 2006. Depression of net ecosystem $\mathrm{CO}_{2}$ exchange in semi-arid Leymus chinensis steppe and alpine shrub. Agric. Forest Meteorol. 137 (3-4), 234-244.
Gao, Z., Horton, R., Liu, H.P., 2010. Impact of wave phase difference between soil surface heat flux and soil surface temperature on soil surface energy balance closure. J. Geophys. Res. 115 (D16), D16112.

Giasson, M.-A., Coursolle, C., Margolis, H.A., 2006. Ecosystem-level $\mathrm{CO}_{2}$ fluxes from a boreal cutover in eastern Canada before and after scarification. Agric. Forest Meteorol. 140 (1-4), 23-40.

Gilmanov, T.G., Soussana, J.F., Aires, L., Allard, V., Ammann, C., Balzarolo, M., Barcza, Z., Bernhofer, C., Campbell, C.L., Cernusca, A., Cescatti, A., Clifton-Brown, J., Dirks, B.O.M., Dore, S., Eugster, W., Fuhrer, J., Gimeno, C., Gruenwald, T., Haszpra, L., Hensen, A., Ibrom, A., Jacobs, A.F.G., Jones, M.B., Lanigan, G., Laurila, T., Lohila, A., Manca, G., Marcolla, B., Nagy, Z., Pilegaard, K., Pinter, K., Pio, C., Raschi, A., Rogiers, N., Sanz, M.J., Stefani, P., Sutton, M., Tuba, Z., Valentini, R., Williams, M.L., Wohlfahrt, G., 2007. Partitioning European grassland net ecosystem $\mathrm{CO}_{2}$ exchange into gross primary productivity and ecosystem respiration using light response function analysis. Agric. Ecosyst. Environ. 121, 93-120.

Gilmanov, T.G., Tieszen, L.L., Wylie, B.K., Flanagan, L.B., Frank, A.B., Haferkamp, M.R., Meyers, T.P., Morgan, J.A., 2005. Integration of $\mathrm{CO}_{2}$ flux and remotely-sensed data for primary production and ecosystem respiration analyses in the Northern Great Plains: potential for quantitative spatial extrapolation. Global Ecol. Biogeogr. 14 (3), 271-292.

Gioli, B., Miglietta, F., De Martino, B., Hutjes, R.W.A., Dolman, H.A.J., Lindroth, A. Schumacher, M., Sanz, M.J., Manca, G., Peressotti, A., Dumas, E.J., 2004. Comparison between tower and aircraft-based eddy covariance fluxes in five European regions. Agric. Forest Meteorol. 127 (1-2), 1-16.

Göckede, M., Foken, T., Aubinet, M., Aurela, M., Banza, J., Bernhofer, C., Bonnefond, J.M., Brunet, Y., Carrara, A., Clement, R., Dellwik, E., Elbers, J., Eugster, W., Fuhrer J., Granier, A., Grünwald, T., Heinesch, B., Janssens, I.A., Knohl, A., Koeble, R., Laurila, T., Longdoz, B., Manca, G., Marek, M., Markkanen, T., Mateus, J., Matteucci, G., Mauder, M., Migliavacca, M., Minerbi, S., Moncrieff, J., Montagnani, L., Moors, E., Ourcival, J.-M., Papale, D., Pereira, J., Pilegaard, K., Pita, G., Rambal, S., Rebmann, C., Rodrigues, A., Rotenberg, E., Sanz, M.J., Sedlak, P., Seufert, G., Siebicke, L., Soussana, J.F., Valentini, R., Vesala, T., Verbeeck, H., Yakir, D., 2008. Quality control of CarboEurope flux data - Part 1: coupling footprint analyses with flux data quality assessment to evaluate sites in forest ecosystems. Biogeosciences 5, 433-450.

Goldstein, A.H., Hultman, N.E., Fracheboud, J.M., Bauer, M.R., Panek, J.A., Xu, M., Qi, Y., Guenther, A.B., Baugh, W., 2000. Effects of climate variability on the carbon dioxide, water, and sensible heat fluxes above a ponderosa pine plantation in the Sierra Nevada (CA). Agric. Forest Meteorol. 101 (2-3), 113-129.

Granier, A., Ceschia, E., Damesin, C., Dufrêne, E., Epron, D., Gross, P., Lebaube, S., Le Dantec, V., Le Goff, N., Lemoine, D., Lucot, E., Ottorini, J.M., Pontailler, J.Y., Saugier, B., 2000. The carbon balance of a young Beech forest. Funct. Ecol. 14(3), 312-325.

Gray, J., 2009. Jim Gray on eScience: a transformed scientific method. In: Hey, T., Tansley, S., Tolle, K. (Eds.), The Fourth Paradigm: Data-intensive Scientific Discovery. Microsoft Research, p. 284

Grunzweig, J.M., Lin, T., Rotenberg, E., Schwartz, A., Yakir, D., 2003. Carbon sequestration in arid-land forest. Global Change Biol. 9 (5), 791-799.

Gu, L., Meyers, T., Pallardy, S.G., Hanson, P.J., Yang, B., Heuer, M., Hosman, K.P., Riggs, J.S., Sluss, D., Wullschleger, S.D., 2006. Direct and indirect effects of atmospheric conditions and soil moisture on surface energy partitioning revealed by a prolonged drought at a temperate forest site. J. Geophys. Res. 111 (D16), D16102.

Guan, D.-X., Wu, J.-B., Zhao, X.-S., Han, S.-J., Yu, G.-R., Sun, X.-M., Jin, C.-J., 2006. CO fluxes over an old, temperate mixed forest in northeastern China. Agric. Forest Meteorol. 137 (3, Äì), 138-149.

Guerschman, J.P., Van Dijk, A.I.J.M., Mattersdorf, G., Beringer, J., Hutley, L.B., Leuning, R., Pipunic, R.C., Sherman, B.S., 2009. Scaling of potential evapotranspiration with MODIS data reproduces flux observations and catchment water balance observations across Australia. J. Hydrol. 369 (1-2), 107-119.

Hargreaves, K.J., Milne, R., Cannell, M.G.R., 2003. Carbon balance of afforested peatland in Scotland. Forestry 76 (3), 299-317.

Haverd, V., Cuntz, M., Leuning, R., Keith, H., 2007. Air and biomass heat storage fluxes in a forest canopy: calculation within a soil vegetation atmosphere transfer model. Agric. Forest Meteorol. 147, 125-139.

Heinsch, F.A., Heilman, J.L., McInnes, K.J., Cobos, D.R., Zuberer, D.A., Roelke, D.L., 2004. Carbon dioxide exchange in a high marsh on the Texas Gulf Coast: effects of freshwater availability. Agric. Forest Meteorol. 125 (1-2), 159-172.

Hendricks Franssen, H.J., Stöckli, R., Lehner, I., Rotenberg, E., Senevirante, S.I., 2010 Energy balance closure of eddy-covariance data: a multisite analysis for European FLUXNET stations. Agric. Forest Meteorol. 150 (12), 1553-1567.

Heusinkveld, B.G., Jacobs, A.F.G., Hostslag, A.A.M., Berkowicz, S.M., 2004. Surface energy balance closure in an arid region: role of soil heat flux. Agric. Forest Meteorol. 122, 21-37.

Hirano, T., Hirata, R., Fujinuma, Y., Saigusa, N., Yamamoto, S., Harazono, Y., Takada, M., Inukai, K.O.H., Inoue, G.E.N., 2003. $\mathrm{CO}_{2}$ and water vapor exchange of a larch forest in northern Japan. Tellus B 55 (2), 244-257.

Hollinger, D.Y., Goltz, S.M., Davidson, E.A., Lee, J.T., Tu, K., Valentine, H.T., 1999. Seasonal patterns and environmental control of carbon dioxide and water vapour exchange in an ecotonal boreal forest. Global Change Biol. 5 (8), 891-902.

Hollinger, D.Y., Ollinger, S.V., Richardson, A.D., Meyers, T., Dail, D.B., Martin, M.E., Scott, N.A., Arkebauer, T.J., Baldocchi, D.D., Clark, K.L., Curtis, P.S., Davis, K.J., Desai, A.R., Dragoni, D., Goulden, M.L., Gu, L., Katul, G.G., Pallardy, S.G., Paw U, K.T., Schmid, H.P., Stoy, P.C., Suyker, A.E., Verma, S.B., 2009. Albedo estimates for land surface models and support for a new paradigm based on foliage nitrogen concentration. Global Change Biol. 16, 696-710.

Hsieh, C.-I., Huang, C.-W., Kiely, G., 2009. Long-term estimation of soil heat flux by single layer soil temperature. Int. J. Biometeorol. 53 (1), 113-123. 
Huete, A. Didan, K., Miura, T. Rodriguez, E.P., Gao, X., Ferreira, L.G., 2002. Overview of the radiometric and biophysical performance of the MODIS vegetation indices. Remote Sens. Environ. 83 (1-2), 195-213.

Humphreys, E.R., Black, T.A., Morgenstern, K., Cai, T., Drewitt, G.B., Nesic, Z., Trofymow, J.A., 2006. Carbon dioxide fluxes in coastal Douglas-fir stands at different stages of development after clearcut harvesting. Agric. Forest Meteorol. 140 (1-4), 6-22.

Hunt, J.R., Baldocchi, D.D., van Ingen, C., 2009. Redefining ecological science using data. In: Hey, T., Tansley, S., Tolle, K. (Eds.), The Fourth Paradigm: Data Intensive Scientific Discovery. Microsoft Research, p. p284.

Hutley, L.B., O'Grady, A.P., Eamus, D., 2000. Evapotranspiration from Eucalypt openforest savanna of Northern Australia. Funct. Ecol. 14 (2), 183-194.

Ibrom, A., Dellwik, E., Jensen, N.O., Klyvbjerg, H., Pilegaard, K., 2007. Strong lowpass filtering effects on water vapour flux measurements with closed-path eddy correlation systems. Agric. Forest Meteorol. 147, 140-156.

Irvine, J., Law, B.E., Kurpius, M.R., Anthoni, P.M., Moore, D., Schwartz, P.A., 2004. Agerelated changes in ecosystem structure and function and effects on water and carbon exchange in ponderosa pine. Tree Physiol. 24, 753-763.

Jacobs, C.M.J., Jacobs, A.F.G., Bosveld, F.C., Hendriks, D.M.D., Hensen, A., Kroon, P.S., Moors, E.J., Nol, L., Schrier-Uijl, A., Veenendaal, E.M., 2007. Variability of annual $\mathrm{CO}_{2}$ exchange from Dutch grasslands. Biogeosciences 4, 803-816.

Jarvis, P.G., Massheder, J.M., Hale, S.E., Moncrieff, J.B., Rayment, M., Scott, S.L., 1997. Seasonal variation of carbon dioxide, water vapor, and energy exchanges of a boreal black spruce forest. J. Geophys. Res. 102 (D24), 28953-28966.

Jassal, R.S., Black, T.A., Novak, M.D., Gaumont-Guay, D., Nesic, Z., 2008. Effect of soil water stress on soil respiration and its temperature sensitivity in an 18-year-old temperate Douglas-fir stand. Global Change Biol. 14 (6), 1305-1318.

Jung, M., Reichstein, M., Bondeau, A., 2009. Towards global empirical upscaling of FLUXNET eddy covariance observations: validation of a model tree ensemble approach using a biosphere model. Biogeosciences 6, 2001-2013.

Jung, M., Reichstein, M., Ciais, P., Senevirante, S.I., Sheffield, J., Goulden, M.L., Bonan, G., Cescatti, A., Chen, J., de Jeu, R., Dolman, A.J., Eugster, W., Gerten, D., gianelle, D., Gobon, N., Heinke, J., Kimball, J.S., Law, B.E., Montagnani, L., Mu, Q., Mueller, B., Oleson, K.W., Papale, D., Richardson, A.D., Roupsard, O., Running, S.W., Tomelleri, E., Viovy, N., Weber, U., Williams, C.A., Wood, E.F., Zaehle, S., Zhang, K., 2011. A recent decline in the global land evapotranspiration trend due to limited moisture supply. Nature 467, 951-954.

Kanda, M., Inagaki, A., Letzel, M.O., Raasch, S., Watanabe, T., 2004. LES study of the energy imbalance problem with eddy covariance fluxes. Boundary-Layer Meteorol. 110, 381-404.

Kanemasu, E.T., Verma, S.B., Smith, E.A., Fritschen, L.Y., Wesley, M., Fild, R.T., Kustas, W.P., Weaver, H., Steawart, Y.B., Geney, R., Panin, G.N., Moncrieff, J.B., 1992. Surface flux measurements in FIFE: an overview. J. Geophys. Res. 97, 18547-18555.

Kidston, J., Brümmer, C., Black, T., Morgenstern, K., Nesic, Z., McCaughey, J., Barr, A., 2010. Energy balance closure using eddy covariance above two different land surfaces and implications for $\mathrm{CO}_{2}$ flux measurements. Boundary-Layer Meteorol. 136 (2), 193-218.

Kim, J., Lee, D., Hong, J., Kang, S., Kim, S.-J., Moon, S.-K., Lim, J.-H., Son, Y., Lee, J., Kim, S., Woo, N., Kim, K., Lee, B., Lee, B.-L., Kim, S., 2006. HydroKorea and CarboKorea: cross-scale studies of ecohydrology and biogeochemistry in a heterogeneous and complex forest catchment of Korea. Ecol. Res. 21 (6), 881-889.

Knohl, A., Schulze, E.-D., Kolle, O., Buchmann, N., 2003. Large carbon uptake by an unmanaged 250-year-old deciduous forest in Central Germany. Agric. Forest Meteorol. 118, 151-167.

Koitzsch, R., Dzingel, M., Foken, T., Mücket, G., 1988. Probleme der experimentellen Erfassung des Energieastausches über Winterweizen. Zeitschrift für Meteorologie $38,150-155$.

Kurbatova, J., Arneth, A., Vygodskaya, N.N., Kolle, O., Varlargin, A.V., Milyukova, I.M., Tchebakova, N.M., Schulze, E.-D., Lloyd, J., 2002. Comparative ecosystem-atmosphere exchange of energy and mass in a European Russian and a central Siberian bog I. Interseasonal and interannual variability of energy and latent heat fluxes during the snowfree period. Tellus B 54 (5), 497-513.

Kurbatova, J., Li, C., Varlagin, A.B., Xiao, X., Vygodskaya, N.N., 2008. Modeling carbon dynamics in two adjacent spruce forests with different soil conditions in Russia. Biogeosciences 5, 969-980.

Kutsch, W.L., Aubinet, M., Buchmann, N., Smith, P., Osborne, B., Eugster, W., Wattenbach, M., Schrumpf, M., Schulze, E.D., Tomelleri, E., Ceschia, E., Bernhofer, C., Beziat, P., Carrara, A., Di Tommasi, P., Grunwald, T., Jones, M., Magliulo, V., Marloie, O., Moureaux, C., Olioso, A., Sanz, M.J., Saunders, M., S $\sqrt{\prod}$ gaard, H., Ziegler, W., 2010. The net biome production of full crop rotations in Europe. Agric. Ecosyst. Environ. 139 (3), 336-345.

Lafleur, P.M., Roulet, N.T., Bubier, J.L., Moore, T.R., Frolking, S., 2003. Interannual variability in the peatland-atmosphere carbon dioxide exchange at an ombrotrophic bog. Global Biogeochem. Cycles 17, 1036.

Lagergren, F., Lindroth, A., Dellwik, E., Ibrom, A., Lankreijer, H., Launiainen, S., Mölder, M., Kolari, P., Pilegaard, K.I.M., Vesala, T., 2008. Biophysical controls on $\mathrm{CO}_{2}$ fluxes of three Northern forests based on long-term eddy covariance data. Tellus B 60 (2), 143-152.

Laville, P., Jambert, C., Cellier, P., Delmas, R., 1999. Nitrous oxide fluxes from a fertilised maize crop using micrometeorological and chamber methods. Agric. Forest Meteorol. 96 (1-3), 19-38.

Law, B.E., Falge, E., Gu, L., Baldocchi, D.D., Bakwin, P., Berbigier, P., Davis, K., Dolman, A.J., Falk, M., Fuentes, J.D., Goldstein, A., Granier, A., Grelle, A., Hollinger, D., Janssens, I.A., Jarvis, P., Jensen, N.O., Katul, G., Mahli, Y., Matteucci, G., Meyers, T., Monson, R., Munger, W., Oechel, W., Olson, R., Pilegaard, K., Paw, K.T.,
Thorgeirsson, H., Valentini, R., Verma, S., Vesala, T., Wilson, K., Wofsy, S., 2002. Environmental controls over carbon dioxide and water vapor exchange of terrestrial vegetation. Agric. Forest Meteorol. 113 (1-4), 97-120.

Law, B.E., Goldstein, A.H., Anthoni, P.M., Unsworth, M.H., Panek, J.A., Bauer, M.R. Fracheboud, J.M., Hultman, N., 2001. Carbon dioxide and water vapor exchange by young and old ponderosa pine ecosystems during a dry summer. Tree Physiol. 21 (5), 299-308.

Lee, H.C., Hong, J., Cho, C.H., Choi, B.C., Oh, S.N., Kim, J., 2003. Surface exchange of energy and carbon dioxide between the atmosphere and a farmland in Haeman, Korea. Korean J. Agric. Forest Meteorol. 5, 61-69.

Leuning, R., van Gorsel, E., Massman, W.J., Issac, P.R., 2012. Reflections on the surface energy imbalance problem. Agric. Forest Meteorol. 156, 65-74.

Leuning, R., Zegelin, S.J., Jones, K., Keith, H., Hughes, D., 2008. Measurement of horizontal and vertical advection of $\mathrm{CO}_{2}$ within a forest canopy. Agric. Forest Meteorol. 148, 1777-1797.

Li, Z.Q., Yu, G.R., Wen, X.F., Zhang, L.M., Ren, C.Y., Fu, Y.L., 2005. Energy balance closure at ChinaFLUX sites. Sci. China Ser. D-Earth Sci. 48, 51-62.

Light, A., Bartlein, P.J., 2004. The end of the rainbow? Color schemes for improved data graphics. Eos Trans. AGU 85 (40).

Lindroth, A., Molder, M., Lagergren, F., 2009. Heat storage in forest biomass improves energy balance closure. Biogeosciences 7, 301-313.

Lipson, D.A., Wilson, R.F., Oechel, W.C., 2005. Effects of elevated atmospheric $\mathrm{CO}_{2}$ on soil microbial biomass, activity, and diversity in a chaparral ecosystem. Appl. Environ. Microbiol. 71 (12), 8573-8580.

Liu, C., Zhang, Z., Sun, G., Zha, T., Zhu, J., Shen, L., Chen, J., Fang, X., Chen, J., 2009. Quantifying evapotranspiration and biophysical regulations of a poplar plantation assessed by eddy covariance and sap-flow methods. J. Plant Ecol. (Chinese Version) 33 (4), 706-718.

Liu, H., Randerson, J.T., Lindfors, J., Chapin III, F.S., 2005. Changes in the surface energy budget after fire in boreal ecosystems of interior Alaska: an annual perspective. J. Geophys. Res. 110 (D13), D13101.

Lund, M., Lindroth, A., Christensen, T.R., Strom, L., 2007. Annual $\mathrm{CO}_{2}$ balance of a temperate bog. Tellus B 59, 804-811.

Ma, S., Baldocchi, D.D., Xu, L., Hehn, T., 2007. Inter-annual variability in carbon dioxide exchange of an oak/grass savanna and open grassland in California. Agric. Forest Meteorol. 147 (3-4), 157-171.

Mahrt, L., 2010. Computing turbulent fluxes near the surface: needed improvements Agric. Forest Meteorol. 150, 501-509.

Malhi, Y., Nobre, A.D., Grace, J., Kruijt, B., Pereira, M.G.P., Culf, A., Scott, S., 1998 Carbon dioxide transfer over a central Amazonian rain forest. J. Geophys. Res. 103 (D24), 31593-31612.

Marcolla, B., Cescatti, A., Manca, G., Zorer, R., Cavagna, M., Fiora, A., Gianelle, D., Rodeghiero, M., Sottocornola, M., Zampedri, R., 2011. Climatic controls and ecosystem responses drive the inter-annual variability of the net ecosystem exchange of an alpine meadow. Agric. Forest Meteorol. 151 $1233-1243$.

Marcolla, B., Cescatti, A., Montagnani, L., Manca, G., Kerschbaumer, G., Minerbi, S. 2005. Importance of advection in the atmospheric $\mathrm{CO}_{2}$ exchanges of an alpine forest. Agric. Forest Meteorol. 130, 193-206.

Maselli, F., Barbati, A., Chiesi, M., Chirici, G., Corona, P., 2006. Use of remotely sensed and ancillary data for estimating forest gross primary productivity in Italy. Remote Sens. Environ. 100 (4), 563-575

Maselli, F., Chiesi, M., Moriondo, M., Fibbi, L., Bindi, M., Running, S.W., 2009 Modelling the forest carbon budget of a Mediterranean region through the integration of ground and satellite data. Ecol. Modell. 220 (3), 330-342.

Matese, A., Alberti, G., Gioli, B., Toscano, P., Vaccari, F.P., Zaldei, A., 2008. Compact_Eddy: a compact, low consumption remotely controlled eddy covariance logging system. Comput. Electron. Agric. 64 (2), 343-346.

Mauder, M., Desjardins, R.L., MacPherson, I., 2007a. Scale analysis of airborne flux measurements over heterogeneous terrain in a boreal ecosystem. J. Geophys. Res. 112, D13112.

Mauder, M., Desjardins, R.L., Pattey, E., Worth, D., 2010. An attempt to close the daytime surface energy balance using spatially-averaged flux measurements. Boundary-Layer Meteorol. 136, 175-191.

Mauder, M., Foken, T., 2006. Impact of post-field data processing on eddy covariance flux estimates and energy balance closure. Meteorologische Zeitschrift 15 (6) 597-609.

Mauder, M., Jegede, O.O., Okogbue, E.C., Wimmer, F., Foken, T., 2007b. Surface energy flux measurements at a tropical site in West-Africa during the transition from dry to wet season. Theor. Appl. Climatol. 89, 171-183.

Mauder, M., Liebethal, C., Göckede, M., Leps, J.-P., Beyrich, F., Foken, T., 2006. Processing and quality control of flux data during LITFASS-2003. Boundary-Layer Meteorol. 121, 67-88

Medlyn, B.E., Robinson, A.P. Clement, R. McMurtrie, R, 2005. On the validation of models of forest $\mathrm{CO}_{2}$ exchange using eddy covariance data: some perils and pitfalls. Tree Physiol. 25, 839-857.

Meyers, T.P., Hollinger, S.E., 2004. An assessment of storage terms in the surface energy balance of maize and soybean. Agric. Forest Meteorol. 125 (1-2) $105-115$.

Miao, H., Chen, S., Chen, J., Zhang, W., Zhang, P., Wei, L., Han, X., Lin, G., 2009. Cultivation and grazing altered evapotranspiration and dynamics in Inner Mongolia steppes. Agric. Forest Meteorol. 149 (11), 1810-1819.

Migliavacca, M., Meroni, M., Manca, G., Matteucci, G., Montagnani, L., Grassi, G. Zenone, T., Teobaldelli, M., Goded, I., Colombo, R., Seufert, G., 2009. Seasonal and interannual patterns of carbon and water fluxes of a poplar plantation under peculiar eco-climatic conditions. Agric. Forest Meteorol. 149 (9), 1460-1476. 
Moderow, U., Aubinet, M., Feigenwinter, C., Kolle, O., Lindroth, A., Mölder, M., Montagnani, L., Rebmann, C., Bernhofer, C., 2009. Available energy and energy balance closure at four coniferous sites across Europe. Theor. Appl. Climatol. 98, 397-412.

Moderow, U., Feigenwinter, C., Bernhofer, C., 2011. Non-turbulent fluxes of carbon dioxide and sensible heat-a comparison of three forested sites. Agric. Forest Meteorol. 151 (6), 692-708.

Moncrieff, J.B., Mahli, Y., Leuning, R., 1996. The propagation of errors in long-term measurements of land-atmosphere fluxes of carbon and water. Global Change Biol. 2, 231-240.

Monson, R.K., Turnipseed, A.A., Sparks, J.P., Harley, P.C., Scott-Denton, L.E., Sparks, K., Huxman, T.E., 2002. Carbon sequestration in a high-elevation, subalpine forest. Global Change Biol. 8 (5), 459-478.

Moors, E.J., Jacobs, C., Jans, W., Supit, I., Kutsch, W.L., Bernhofer, C., Béziat, P., Buchmann, N., Carrara, A., Ceschia, E., Elbers, J., Eugster, W., Kruijt, B., Loubet, B., Magliulo, E., Moureaux, C., Olioso, A., Saunders, M., Soegaard, H., 2010. Variability in carbon exchange of European croplands. Agric. Ecosyst. Environ. 139 (3), 325-335.

Morgenstern, K., Black, T.A., Humphreys, E.R., Griffis, T.J., Drewitt, G.B., Cai, T.B., Nesic, Z., Spittlehouse, D.L., Livingstone, N.J., 2004. Sensitivity and uncertainty of the carbon balance of a Pacific Northwest Douglas-fir forest during an El Niño/La Niña cycle. Agric. Forest Meteorol. 123 (3-4), 201-219.

Moureaux, C., Debacq, A., Bodson, B., Heinesch, B., Aubinet, M., 2006. Annual net ecosystem carbon exchange by a sugar beet crop. Agric. Forest Meteorol. 139 (1-2), 25-39.

Nagy, Z., Czóbel, S., Balogh, J., Horváth, L., Fóti, S., Pintér, K., Weidinger, T., Csintalan, Z., Tuba, Z., 2005. Some preliminary results of the Hungarian grassland ecological research: carbon cycling and greenhouse gas balances under changing. Cereal Res. Commun. 33 (1), 279-281.

Nakai, T., van der Molen, M.K., Gash, J.H.C., Kodama, Y., 2006. Correction of sonic anemometer angle of attack errors. Agric. Forest Meteorol. 136, 19-30.

Nardino, M., Georgiadis, T., Rossi, F., Ponti, F., Miglietta, F., Magliulo, V., 2002. Primary productivity and evapotranspiration of a mixed forest. In: Congress CNR-I.S.A. Fo, Istituto per i Sistemi Agricoli e Forestali del Mediterraneo, Portici, Italy.

Noormets, A., Chen, J., Crow, T., 2007. Age-dependent changes in ecosystem carbon fluxes in managed forests in northern Wisconsin, USA. Ecosystems 10 (2), 187-203.

Noormets, A., Gavazzi, M.J., McNulty, S.G., Domec, J.-C., Sun, G.E., King, J.S., Chen, J., 2010. Response of carbon fluxes to drought in a coastal plain loblolly pine forest. Global Change Biol. 16 (1), 272-287.

Oncley, S., Foken, T., Vogt, R., Kohsiek, W., DeBruin, H., Bernhofer, C., Christen, A., Gorsel, E., Grantz, D., Feigenwinter, C., Lehner, I., Liebethal, C., Liu, H., Mauder, M., Pitacco, A., Ribeiro, L., Weidinger, T., 2007. The Energy Balance Experiment EBEX-2000 Part I: overview and energy balance. Boundary-Layer Meteorol. 123 (1), 1-28.

Oren, R., Hsieh, C.I., Stoy, P.C., Albertson, J.D., McCarthy, H.R., Harrell, P., Katul, G.G., 2006. Estimating the uncertainty in annual net ecosystem carbon exchange: spatial variation in turbulent fluxes and sampling errors in eddy-covariance measurements. Global Change Biol. 12, 883-896.

Owen, K.E., Tenhunen, J., Reichstein, M., Wang, Q., Falge, E., Geyer, R., Xiao, X., Stoy, P.C., Amman, C., Arain, A., Aubinet, M., Aurela, M., Bernhofer, C., Chojnicki, B., Granier, A., Gruenwald, T., Hadley, J., Heinesch, B., Hollinger, D., Knohl, A., Kutsch, W., Laurila, T., Lohila, A., Meyers, T., Moors, E., Moureaux, C., Verma, S., Vesala, T., Vogel, C.S., 2007. Linking flux network measurements to continental scale simulations: ecosystem carbon dioxide exchange capacity under non-waterstressed conditions. Global Change Biol. 13, 734-760.

Panin, G.N., Bernhofer, C., 2008. Parameterization of turbulent flux over inhomogeneous landscapes. Atmosph. Oceanic Phys. 44, 701-716.

Panin, G.N., Tetzlaff, G., Raabe, A., 1998. Inhomogeneity of the land surface and problems in the parameterization of surface fluxes in natural conditions. Theor. Appl. Climatol. 60, 163-178.

Papale, D., Reichstein, M., Aubinet, M., Canfora, E., Bernhofer, C., Kutsch, W., Longdoz, B., Rambal, S., Valentini, R., Vesala, T., Yakir, D., 2006. Towards a standardized processing of Net Ecosystem Exchange measured with eddy covariance technique: algorithms and uncertainty estimation. Biogeosciences 3, 571-583.

Peichl, M., Arain, M.A., 2007. Allometry and partitioning of above- and belowground tree biomass in an age-sequence of white pine forests. Forest Ecol. Manag. 253 $(1-3), 68-80$

Peichl, M., Leahy, P., Kiely, G., 2011. Six-year stable annual uptake of carbon dioxide in intensively managed humid temperate grassland. Ecosystems 14 (1), 112-126.

Pejam, M.R., Arain, M.A., McCaughey, J.H., 2006. Energy and water vapour exchanges over a mixedwood boreal forest in Ontario Canada. Hydrol. Process. 20 (17), 3709-3724.

Pereira, J.S., Mateus, J.A., Aires, L.M., Pita, G., Pio, C., David, J.S., Andrade, V., Banza, J., David, T.S., Paco, T.A., Rodrigues, A., 2007. Net ecosystem carbon exchange in three contrasting Mediterranean ecosystems? The effect of drought. Biogeosciences 4, 791-802

Pilegaard, K., Hummelshoj, P., Jensen, N.O., Chen, Z., 2001. Two years of continuous $\mathrm{CO}_{2}$ eddy-flux measurements over a Danish beech forest. Agric. Forest Meteorol. 107 (1), 29-41.

Powell, T.L, Bracho, R., Li, J., Dore, S., Hinkle, C.R., Drake, B.G., 2006. Environmental controls over net ecosystem carbon exchange of scrub oak in central Florida. Agric. Forest Meteorol. 141 (1), 19-34.

Rambal, S., Joffre, R., Ourcival, J.-M., 2004. The growth respiration component in eddy $\mathrm{CO}_{2}$ flux from a Quercus ilex mediterranean forest. Global Change Biol. 10, 1460-1469.
Reichstein, M., Falge, E., Baldocchi, D., Papale, D., Aubinet, M., Berbigier, P., Bernhofer C., Buchmann, N., Gilmanov, T.G., Granier, A., Grünwald, T., Havránková, K., Ilvesniemi, H., Janous, D., Knohl, A., Laurila, T., Lohila, A., Loustau, D., Matteucci, G., Meyers, T., Miglietta, F., Ourcival, J.-M., Pumpanen, J., Rambal, S., Rotenberg, E., Sanz, M., Tenhunen, J., Seufert, G., Vaccari, F., Vesala, T., Yakier, D., Valentini, R., 2005. On the separation of net ecosystem exchange into assimilation and ecosystem respiration: review and improved algorithm. Global Change Biol. 11, 1424-1439.

Reichstein, M., Rey, A., Freibauer, A., Tenhunen, J., Valentini, R., Banza, J., Casals, P., Cheng, Y., Gŗnzweig, J.M., Irvine, J., Joffre, R., Law, B.E., Loustau, D., Miglietta, F., Oechel, W., Ourcival, J.-M., Pereira, J.S., Peressotti, A., Ponti, F., Qi, Y., Rambal, S., Rayment, M., Romanya, J., Rossi, F., Tedeschi, V., Tirone, G., Xu, M., Yakir, D. 2003. Modeling temporal and large-scale spatial variability of soil respiration from soil water availability, temperature and vegetation productivity indices. Global Biogeochem. Cycles 17 (4), 1104.

Reichstein, M., Tenhunen, J.D., Roupsard, O., Ourcival, J.-m., Rambal, S., Miglietta, F., Peressotti, A., Pecchiari, M., Tirone, G., Valentini, R., 2002. Severe drought effects on ecosystem $\mathrm{CO}_{2}$ and $\mathrm{H}_{2} \mathrm{O}$ fluxes at three Mediterranean evergreen sites: revision of current hypotheses? Global Change Biol. 8 (10), 999-1017.

Rey, A., Pegoraro, E., Tedeschi, V., De Parri, I., Jarvis, P.G., Valentini, R., 2002. Annual variation in soil respiration and its components in a coppice oak forest in Central Italy. Global Change Biol. 8 (9), 851-866.

Ruppert, J., Thomas, C., Foken, T., 2006. Scalar similarity for relaxed eddy accumulation. Boundary-Layer Meteorol. 120, 39-63.

Saito, M., Miyata, A., Nagai, H., Yamada, T., 2005. Seasonal variation of carbon dioxide exchange in rice paddy field in Japan. Agric. Forest Meteorol. 135 (1-4), 93-109.

Saleska, S.R., Miller, S.D., Matross, D.M., Goulden, M., Wofsy, S., da Rocha, H.R., de Camargo, P.B., Crill, P., Daube, B.C., de Freitas, H.C., Hutyra, L., Keller, M., Kirchhoff V., Menton, M., Munger, J.W., Pyle, E.H., Rice, A.H., Silva, H., 2003. Carbon in amazon forests: unexpected seasonal fluxes and disturbance-induced losses. Science 302, 1554-1557.

Sanchez, J.M., Caselles, V., Rubio, E.M., 2010. Analysis of the energy balance closure over a FLUXNET boreal forest in Finland. Hydrol. Earth Syst. Sci. 14 1487-1497.

Sanz, M.J., Carrara, A., Gimeno, G., Bucher, A., Lopez, R., 2004. Effects of a dry and warm summer conditions on $\mathrm{CO}_{2}$ and energy fluxes from three mediterranean ecosystems. Geophys. Res. Abstr. 6, 3239

Schmid, H.P., Grimmond, C.S.B., Cropley, F., Offerle, B., Su, H.B., 2000. Measurements of $\mathrm{CO}_{2}$ and energy fluxes over a mixed hardwood forest in the mid-western United States. Agric. Forest Meteorol. 103 (4), 357-374.

Scott, R.L., Hamerlynck, E.P., Jenerette, G.D., Moran, M.S., Barron-Gafford, G.A., 2010 Carbon dioxide exchange in a semidesert grassland through drought-induced vegetation change. J. Geophys. Res. 115 (G3), G03026.

Scott, R.L., Jenerette, G.D., Potts, D.L., Huxman, T.E., 2009. Effects of seasonal drought on net carbon dioxide exchange from a woody-plant-encroached semiarid grassland. J. Geophys. Res. 114, G04004.

Serrano-Ortiz, P., Kowalski, A., Domingo, F., Rey, A., Pegoraro, E., Villagarcía, L. Alados-Arboledas, L., 2007. Variations in daytime net carbon and water exchange in a montane shrubland ecosystem in southeast Spain. Photosynthetica 45 (1), 30-35.

Shannon, C.E., 1948. A mathematical theory of communication. Bell System Techn. J. 27, 379-423; 623-656.

Shen, S., Leclerc, M.Y., 1995. How large must surface inhomogeneities be before they influence the convective boundary layer structure? A case study. Quart. J. Royal Meteorol. Soc. 121 (526), 1209-1228.

Skiba, U., Drewer, J., Tang, Y.S., van Dijk, N., Helfter, C., Nemitz, E., Famulari, D., Cape, J.N., Jones, S.K., Twigg, M., Pihlatie, M., Vesala, T., Larsen, K.S., Carter, M.S., Ambus, P., Ibrom, A., Beier, C., Hensen, A., Frumau, A., Erisman, J.W., Brüggemann, N., Gasche, R., Butterbach-Bahl, K., Neftel, A., Spirig, C., Horvath, L., Freibauer, A. Cellier, P., Laville, P., Loubet, B., Magliulo, E., Bertolini, T., Seufert, G., Andersson, M., Manca, G., Laurila, T., Aurela, M., Lohila, A., Zechmeister-Boltenstern, S. Kitzler, B., Schaufler, G., Siemens, J., Kindler, R., Flechard, C., Sutton, M.A., 2009. Biosphere-atmosphere exchange of reactive nitrogen and greenhouse gases at the NitroEurope core flux measurement sites: measurement strategy and first data sets. Agric. Ecosyst. Environ. 133, 139-149.

Soegaard, H., Jensen, N.O., Boegh, E., Hasager, C.B., Schelde, K., Thomsen, A., 2003 Carbon dioxide exchange over agricultural landscape using eddy correlation and footprint modelling. Agric. Forest Meteorol. 114 (3-4), 153-173.

Sogachev, A.F., LeClerc, M.Y., Zhang, G., Rannik, Ü., Vesala, T., 2008. $\mathrm{CO}_{2}$ fluxes near a forest edge: a numerical study. Ecol. Appl. 18, 1454-1469.

Soussana, J.F., Allard, V., Pilegaard, K., Ambus, P., Amman, C., Campbell, C., Ceschia, E., Clifton-Brown, J., Czobel, S., Domingues, R., Flechard, C., Fuhrer, J., Hensen, A., Horvath, L., Jones, M., Kasper, G., Martin, C., Nagy, Z., Neftel, A., Raschi, A., Baronti, S., Rees, R.M., Skiba, U., Stefani, P., Manca, G., Sutton, M., Tuba, Z., Valentini, R., 2007. Full accounting of the greenhouse gas $\left(\mathrm{CO}_{2}, \mathrm{~N}_{2} \mathrm{O}\right.$, $\mathrm{CH}_{4}$ ) budget of nine European grassland sites. Agric. Ecosyst. Environ. 121, 121-134.

Staebler, R.M., Fitzjarrald, D., 2004. Observing subcanopy $\mathrm{CO}_{2}$ advection. Agric. Forest Meteorol. 122, 139-156.

Steinfeld, G., Letzel, M.O., Raasch, S., Kanda, M., Inagaki, A., 2007. Spatial representativeness of single tower measurements and the imbalance problem with eddy-covariance fluxes: results of a large-eddy simulation study. BoundaryLayer Meteorol. 123, 77-98.

Stoy, P.C., Richardson, A.D., Baldocchi, D.D., Katul, G.G., Stanovick, J., Mahecha, M.D., Reichstein, M., Detto, M., Law, B.E., Wohlfahrt, G., Arriga, N., Campos, J., McCaughey, J.H., Montagnani, L., Paw U, K.T., Sevanto, S., Williams, M., 2009. 
Biosphere-atmosphere exchange of $\mathrm{CO}_{2}$ in relation to climate: a cross-biome analysis across multiple time scales. Biogeosciences 6, 2297-2312.

Suni, T., Rinne, J., Reissell, A., Altimir, N., Keronen, P., Rannik, U., Dal Maso, M., Kulmala, M., Vesala, T., 2003. Long-term measurements of surface fluxes above a Scots pine forest in Hyytiala, southern Finland, 1996-2001. Boreal Environ. Res. 8, 287-301.

Tedeschi, V., Rey, A.N.A., Manca, G., Valentini, R., Jarvis, P.G., Borghetti, M., 2006. Soil respiration in a Mediterranean oak forest at different developmental stages after coppicing. Global Change Biol. 12 (1), 110-121.

Teklemariam, T., Staebler, R.M., Barr, A.G., 2009. Eight years of carbon dioxide exchange above a mixed forest at Borden. Ontario. Agric. Forest Meteorol. 149, 2040-2053.

Thum, T., Aalto, T., Laurila, T., Aurela, M., Kolari, P., Hari, P., 2007. Parametrization of two photosynthesis models at the canopy scale in a northern boreal Scots pine forest. Tellus B 59 (5), 874-890.

Tirone, G., Dore, S., Matteucci, G., Greco, S., Valentini, R., 2003. Evergreen mediterranean forests: carbon and water fluxes, balances, ecological and ecophysiological determinants. In: Valentini, R. (Ed.), Fluxes of Carbon, Water and Energy of European Forests. Springer-Verlag, Berlin.

Tsvang, L.R., Federov, M.M., ader, B.A., Zubkovskii, S.L., Foken, T., Richter, S.H., Zeleny, J., 1991. Turbulent exchange over a surface with chessboard-type inhomogeneities. Boundary-Layer Meteorol. 55, 141-160.

Twine, T.E., Kustas, W.P., Norman, J.M., Cook, D.R., Houser, P.R., Meyers, T.P., Prueger, J.H., Starks, P.J., Wesely, M.L., 2000. Correcting eddy-covariance flux underestimates over a grassland. Agric. Forest Meteorol. 103 (3), 279-300.

Valentini, R., De Angelis, P., Matteucci, G., Monaco, R., Dore, S., Mucnozza, G.E.S., 1996. Seasonal net carbon dioxide exchange of a beech forest with the atmosphere. Global Change Biol. 2 (3), 199-207.

Valentini, R., Matteucci, G., Dolman, A.J., Schulze, E.D., Rebmann, C., Moors, E.J., Granier, A., Gross, P., Jensen, N.O., Pilegaard, K., Lindroth, A., Grelle, A., Bernhofer, C., Grunwald, T., Aubinet, M., Ceulemans, R., Kowalski, A.S., Vesala, T. Rannik, U., Berbigier, P., Loustau, D., Guomundsson, J., Thorgeirsson, H., Ibrom, A., Morgenstern, K., Clement, R., Moncrieff, J., Montagnani, L., Minerbi, S., Jarvis, P.G., 2000. Respiration as the main determinant of carbon balance in European forests. Nature 404 (6780), 861-865.

Veenendaal, E.M., Kolle, O., Lloyd, J., 2004. Seasonal variation in energy fluxes and carbon dioxide exchange for a broad-leaved semi-arid savanna (Mopane woodland) in Southern Africa. Global Change Biol. 10 (3), 318-328.

Verma, S.B., Baldocchi, D.D., Anderson, D.E., Matt, D.R., Clement, R.J., 1986. Eddy fluxes of $\mathrm{CO}_{2}$, water vapor, and sensible heat over a deciduous forest. BoundaryLayer Meteorol. 36 (1), 71-91.
Verma, S.B., Dobermann, A., Cassman, K.G., 2005. Annual carbon dioxide exchange in irrigated and rainfed maize-based agroecosystems. Agric. Forest Meteorol. 131, 77-96.

Vickers, D., Thomas, C., Law, B.E., 2009. Random and systematic $\mathrm{CO}_{2}$ flux sampling errors for tower measurements over forests in the convective boundary layer. Agric. Forest Meteorol. 149 (1), 73-83.

Voronovich, V., Kiely, G., 2007. On the gap in the spectra of surface-layer atmospheric turbulence. Boundary-Layer Meteorol. 122 (1), 67-83.

Vourlitis, G.L., Oechel, W.C., 1999. Eddy covariance measurements of $\mathrm{CO}_{2}$ and energy fluxes of an Alaskan tussock tundra ecosystem. Ecology 80 686-701.

Wang, Y., Zhou, G., Wang, Y., 2008. Environmental effects on net ecosystem $\mathrm{CO}_{2}$ exchange at half-hour and month scales over Stipa krylovii steppe in northern China. Agric. Forest Meteorol. 148 (5), 714-722.

Wilkinson, M., Eaton, E.L., Broadmeadow, M.S.J., Morison, J.I.L., 2012. Inter-annua variation of carbon uptake by a plantation oak woodland in south-eastern England. Biogeosci. Discuss. 9, 9667-9710.

Wilske, B., Lu, N., Wei, L., Chen, S., Zha, T., Liu, C., Xu, W., Noormets, A., Huang, J., Wei, Y., Chen, J., Zhang, Z., Ni, J., Sun, G., Guo, K., McNulty, S., John, R., Han, X., Lin, G., Chen, J., 2009. Poplar plantation has the potential to alter the water balance in semiarid Inner Mongolia. J. Environ. Manag. 90 (8), 2762-2770.

Wilson, K., Goldstein, A., Falge, E., Aubinet, M., Baldocchi, D., Berbigier, P., Bernhofer C., Ceulemans, R., Dolman, H., Field, C., Grelle, A., Ibrom, A., Law, B.E., Kowalski, A., Meyers, T., Moncrieff, J., Monson, R., Oechel, W., Tenhunen, J., Valentini, R., Verma, S., 2002. Energy balance closure at FLUXNET sites. Agric. Forest Meteorol $113,223-243$.

Wilson, T.B., Meyers, T.P., 2007. Determining vegetation indices from solar and photosynthetically active radiation fluxes. Agric. Forest Meteorol. 144, 160-179.

Wohlfahrt, G., Hammerle, A., Haslwanter, A., Bahn, M., Tappeiner, U., Cernusca, A. 2008. Seasonal and inter-annual variability of the net ecosystem $\mathrm{CO} 2$ exchange of a temperate mountain grassland: effects of weather and management. J. Geophys. Res. 113 (D8), D08110.

Yan, Y., Zhao, B.I.N., Chen, J., Guo, H., Gu, Y., Wu, Q., Li, B.O., 2008. Closing the carbon budget of estuarine wetlands with tower-based measurements and MODIS time series. Global Change Biol. 14 (7), 1690-1702.

Yu, G.-R., Wen, X.-F., Sun, X.-M., Tanner, B.D., Lee, X., Chen, J.-Y., 2006. Overview of ChinaFLUX and evaluation of its eddy covariance measurement. Agric. Forest Meteorol. 137 (3-4), 125-137.

Zhang, W.L., Chen, S.P., Chen, J., Wei, L., Han, X.G., Lin, G.H., 2007. Biophysical regulations of carbon fluxes of a steppe and a cultivated cropland in semiarid Inner Mongolia. Agric. Forest Meteorol. 146 (3-4), 216-229. 